\title{
The Singapore Mass Rapid Transport: A case study of the efficacy of a democratised political humour landscape in a critical engagement in the public sphere
}

\author{
Chen Khin Wee \\ University of Canterbury, New Zealand
}

\begin{abstract}
Political cartoons can function as a means of monitoring the level of press freedom, of government's tolerance of free speech, and their resistance to challenges posed by opposition. It may also be argued that in this digital age the aforesaid barometric utility can extend to other satirical visual forms like memes and videos. Singapore has a long reputation for its strict media control, iron-grip on the mainstream media, and zero-tolerance for any form of spontaneous public protest. However, the arrival of the digital information age effectively eroded the government's hegemony over the public sphere, resulting in a revitalisation of democracy and the empowerment of a traditionally docile and acquiescent citizenry with regards to politics. As with most socio-political struggles in the past, political humour can be seen playing once again an important role in the expression of dissent and criticism of the establishment in the island-state. However, unlike in the past when such political humour was the domain of a small group of professional artists and writers, the new media with its immense capabilities like powerful search engines, social networks, YouTube, Twitter and various computer applications like Photoshop and Macromedia Flash, has for the first time provided tools for ordinary people who hitherto may have lived in fear of voicing their dissatisfaction all their lives, but are now empowered to create their individual and personalised expressions of protest through the use of Internet memes and other techniques, sometimes within hours of a piece of news breaking. This paper presents a case study that demonstrates how political humour "of the people, by the people" helped fuel a public outcry against the incompetence and negligence of a Singapore public transport provider that had resulted in a series of major breakdown that brought great embarrassment to a country known for its ability to "make things work". The public's demand for accountability has led to the unprecedented resignation of the Chief Executive Officer.
\end{abstract}

Keywords: political humour, Internet memes, Singapore, media control, democratisation.

Open-access journal | EJHR: www.europeanjournalofhumour.org 


\section{Background information on Singapore and the media}

Singapore has strict media control, an iron grip on the mainstream, media and zero-tolerance for any form of spontaneous public protest. Reporters Without Borders ranked Singapore at $135^{\text {th }}$ position behind neighbours Malaysia $\left(122^{\text {nd }}\right)$ and Brunei $\left(125^{\text {th }}\right)$ but ahead of Thailand $\left(137^{\text {th }}\right)$ and Indonesia $\left(146^{\text {th }}\right)$ (Reporters Without Borders 2011).

On January 12, 2009, Human Rights Watch reported the arrest of a two-man demonstration in Singapore for "protesting against what they say is unfair treatment of Singapore-based Burmese nationals who took part in a mass demonstration in front of the Burmese embassy here last year during their country's vote on a constitutional referendum". This arrest prompted deputy Asia director, Phil Robertson, to describe the tiny city-state as "a textbook example of a politically repressive state" ("Singapore: 'Textbook Example' of Repressive State" 2010).

When the Internet first arrived on the shores of Singapore the government lost no time in taking action to regulate it and in July 1996, “...the Singapore Broadcasting Authority, announced new rules and the Class Licensing Scheme to regulate the Internet content" (Ang 2007: 19). Although the government quickly discovered the exertion of total control over the Internet is impossible, it did not weaken its stance and instead took measures to intimidate users to not take too much liberty with the Internet. An example of this kind of bluffing is their decision to ban "access to two pornographic websites in a 'symbolic statement' of the country's societal values" (Lee 2008). The bluff worked as most Singaporeans, conditioned by years of intimidation, continue to self-censor and refrained from pushing the limits of what has become known as the Out of Bounds (OB) markers which will be discussed later.

Hitherto, the citizens were quite happy to trade their freedom of speech for a country and society where, as the average Singaporean would be proud to say, "things here work" (Chang 2011). Within just several decades after its independence from its British colonial master, Singapore had emerged as a thriving, modern, wealthy and cosmopolitan nation. "A study of the world's economies has shown that Singapore had the highest gross domestic product (GDP) per capita in the world in 2010" (Lim 2012). However, Singapore appears to have fallen victim to its own success, as it is now the wealthier and more educated segment of the population, the very people nurtured by the government's progressive policies in education and development that is growing increasingly critical of key governmental policies. Their list of grouses encompasses a wide range of issues such as the rising cost of healthcare; a pressure-cooker education system that stresses its students with multiple exams and at the same time stifles creativity and critical thinking; the lack of transparency in how taxpayers' money is managed, for example the Central Provident Fund; the excessive ministers' salary, which is "the highest salary of any elected head of government in the world-more than four times as much as Barack Obama and David Cameron" ("Singapore backlash against political pay rates despite cut" 2012); the rising public housing prices and shortage of new homes for first-time homeowners; as well as an overcrowded public transportation system that is groaning under the weight of a liberal immigration policy that has brought in en masse what the government labels as "foreign talents", and which has resulted in native Singaporeans being reduced to a mere 63 per cent of the total population (Department of Statistics Singapore 2012). What some would describe as "cracks" within the society (Loh 2007) has led to the People's Action Party (PAP) - the dominant and the only ruling party Singapore has known since its independence in 1969-suffering an embarrassing general election in February 2011 where it suffered a deceptively small drop of 6.5 per cent in votes, but in reality was tantamount to a significant slap in the face of the authoritarian group ("Parliamentary General Election" 2011).

A contributing factor to the government's poorer performance had been attributed to the younger, increasingly bolder, and more vocal netizens who pose a sharp contrast to the loyal, 
docile and politically apathetic older generation who feel that they owe their current wellbeing to the efforts of the PAP in the past. The younger generation feels they owe the PAP no such loyalty and take the present wealth in the country for granted. Wall Street Journal noted this shift, reporting that "[a]lthough Singapore has long had a reputation for limited press freedoms, a thriving online media market has emerged recently, with blogs and other websites taking shots at elected officials and stirring up debate on a range of social and political issues in the wealthy city-state" (Mahtani 2012).

\subsection{Political humour in Singapore}

Since the country's independence political humour in the form of editorial cartoons has not been featured in the government-controlled mainstream media and this is by design. Its exclusion is a function of the intentionally ambiguous and often arbitrary out-of-bounds (OB marker) concept mentioned earlier which came into formalised being in 1994 as a result of a public altercation between political commentator Catherine Lim and the then Prime Minister Goh Chok Tong (Lee T 2002: 109). Making fun of political leaders was described by ex-PM Goh as disrespectful and has the effect of undermining people's confidence in the government, which was deemed unacceptable in a "Confucianist "Asian context" (Chua 1994: 1, cited by Lee 2002). However, the Washington Post had noted that nevertheless "[p]olitical humour is playing a bigger role than ever in the city-state, and despite [the] government's insistence that politics is no laughing matter, satirical websites are blossoming" (De Clercq 2006). On the other hand, Washington Post also observed that, aside from Colin Goh, former lawyer turned writer, satirist, cartoonist and founder of the Mr Brown show, "others do not want to reveal their identities, they are too scared" which underscores the climate of fear that continues to exist.

August 2006 saw a coming-out of sorts for the closet political humourist when TalkingCock.com, the leading satirical website chalked a milestone by holding "its first spoken word "live event"" ("the mrbrown show (video): TalkingCock in Parliament, Hossan Leong" 2006), where radio DJ, actor and comedian Hossan Leong sang and recorded a satirical account of Singapore's history from its birth to the present day. The humorous song, which contained some barbs aimed at the government and even a few for the first Prime Minister and strong man Lee Kuan Yew, raised many a nervous eyebrow. To the surprise of many, no sanctions were taken against the organisers, which led to Asian Correspondent's suggestion that Leong was able to get away with "breaking such taboos" by

adopting the role played by court jesters in England during the Middle Ages. While the people were forbidden from speaking ill of the monarchy - sometimes on pain of death - the jesters were allowed free reign to mock and parody because it was accepted that anything they said was "in jest" and that they were merely the court fool

(Bland 2009)

\section{SMRT: The case study}

The subject of the present case study, Singapore Mass Rapid Transit (SMRT), is the major operator of Singapore's main intra-city railway network (MRT). It also owns a large fleet of public buses and taxis. Although it is government-assisted and its fare structure is regulated by the Public Transport Council, it is a public-listed and profit-based company. SMRT is the second largest public transportation company. In land-scarce Singapore, where car ownership is actively and forcefully discouraged through the imposition of extremely high taxes and a host of overwhelming disincentives, the general population is forced to be almost completely 
dependent on the services of primarily the MRT in addition to the public bus network and taxis. Incorporated in 1987, it had all the while provided an extremely reliable service with no notable major breakdowns for the last 20 years; something Singaporeans have taken great pride in and take for granted. This case study tracks the sudden turn of events when the company suffered a massive loss of confidence due to a series of major breakdowns and public relations faux pas, which fired the rise of a form of socio-political satire and online humour hitherto unseen in Singapore. This was accomplished by just a small group of people who were then able to shape the public's perception to the point of pressuring the Chief Executive Officer to take the unprecedented step of resigning from her post.

This is an important case study for several reasons. Firstly, the Singapore public has never been outspoken in criticising those in authority. Although SMRT is not directly part of the government, it is perceived as a part of the government due to the key members of the leadership who have links to the government. The forceful online assault by ordinary citizens on a public figure, especially one closely associated with the corridors of power is uncommon. Secondly, the culture in Singapore has always been top-heavy in terms of its management style, be it in the corporate or the public sector. Decisions made at the top level hardly ever take into consideration the input from the lower ranks. So any effort by the lower hierarchy to influence decisions made higher up is highly unusual. That the CEO of SMRT gave in to pressure for no other observable reasons than the online attack indicates a significant milestone in how ordinary Singaporeans now engage with socio-political issues using the online platform, and through the use of socio-political humour. This takes the form of YouTube videos, satirical writings, parodies and Internet memes, of which the latter is in many ways a remediated form of political cartoon. For this case study, the Internet meme was the unit of analysis.

\subsection{SMRT woes}

The rock solid confidence of the public that the transport operator had been enjoying for many years could not have been shaken by just a single event. Instead, it took a series of incidents to erode the public's faith; incidents that include a couple of serious security breaches, the increasing overcrowded trains, the aforementioned breakdowns, as well as some minor incidents involving its bus and taxi subsidiaries, which will not be discussed in this paper as it is outside of the intended scope.

\subsubsection{Vandalism}

On two occasions — once on 17 May 2010 and again on 17 Aug 2011 — vandals breached the supposedly high security of SMRT's depot and spray-painted elaborate graffiti art on several train coaches (Suparto 2010; Teoh 2011). Since the September 11 terrorist attack in New York, Singapore too has been on high security alert and Singaporeans were constantly bombarded with public service announcements to be constantly vigilant. These include messages put up by none other than SMRT itself via its announcement screens in all its station and over the PA system on their trains. Commuters were continually reminded to be on the lookout for "suspicious looking persons or articles", which should be immediately reported. This obsessive fear is not unfounded, as the US-friendly island-state is indeed deemed as a real, potential target for an act of terrorism and Singaporeans were conditioned to have a heightened sensitivity to potential terrorist threats. When the vandalised trains were reported there was shocked disbelief and indignation. 
Insult was added to injury because the vandalised train (see Figure1) remained in service for two whole days before the alarm was raised, and even then only when members of the public posted pictures and videos of the decorated coaches online. Staff members who saw the graffiti did not report it because they had assumed it to be part of some artwork for a publicity campaign or advertisement as there had been in the past. This was the first indication of poor internal communication within the organisation.

Figure 1. The vandalised train (Source: (Singapore Seen 2010).

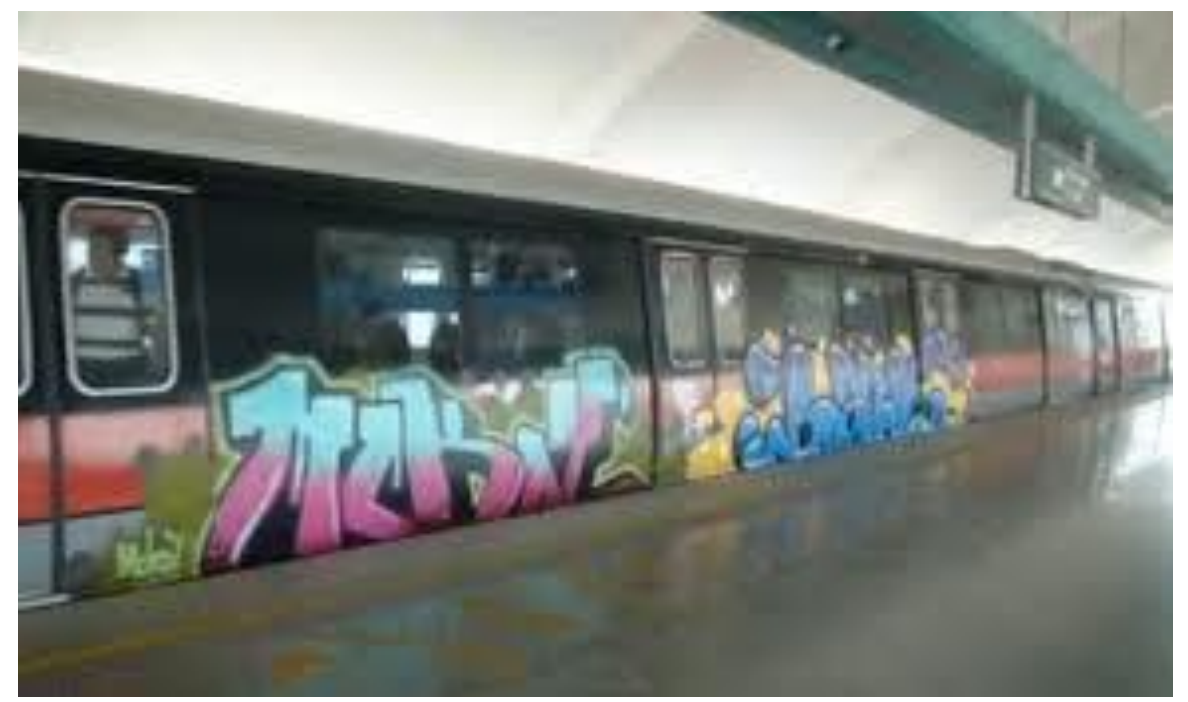

\subsubsection{Overcrowding}

Singapore's liberal immigration policy had led to a sudden influx of foreigners entering the country to work and live. In 2010 alone a total of 29,265 people were granted permanent residence status and 18,758 granted citizenship ("Population in Brief" 2011). The effects of this policy were felt most keenly by the commuter. Tempers fray and patience wear thin when Singaporeans, unaccustomed to fighting for space during their daily commute, had woken up one morning to find themselves battling a sea of people in overcrowded trains and buses. With the large in-flow of aliens came problems precipitated by social and cultural differences in habits and practices between the outsiders and the locals. Although not responsible for this invasion of foreigners, angry commuters nevertheless directed their frustration at the transport company for not taking measures to anticipate and alleviate the situation by providing more frequent train services and by expanding the infrastructure. The Chief Executive of SMRT, Saw Phaik Hwa, was famously reported to have remarked that "people can board the train it's whether they choose to", which further enraged the citizens, prompting blogger-artist, Cheong (2011a) to post one of the first Internet memes that poses a rhetorical question of her statement (Figure 2). Internet memes, in this study is used in the widest sense encompassing a range of digitally embedded ideas that could include hyperlinks, images, digital audios and videos, which could be spread from person to person through the internet. It may or may not be humorous, although the samples in this case study focus on the ones that employ sarcasm, irony, wit and word-play generally to achieve a humorous effect.

Following that first meme, another in the form of a parody motivational poster, technically called demotivational posters by online users, like the one in Figure 3, was released which framed Saw's remark as a parody of sage advice. Saw in her personal blog subsequently defended herself and asserted that she was quoted out of context. 
Figure 2. MRT overcrowding and CEO's “stupid remarks” (Lee 2011).

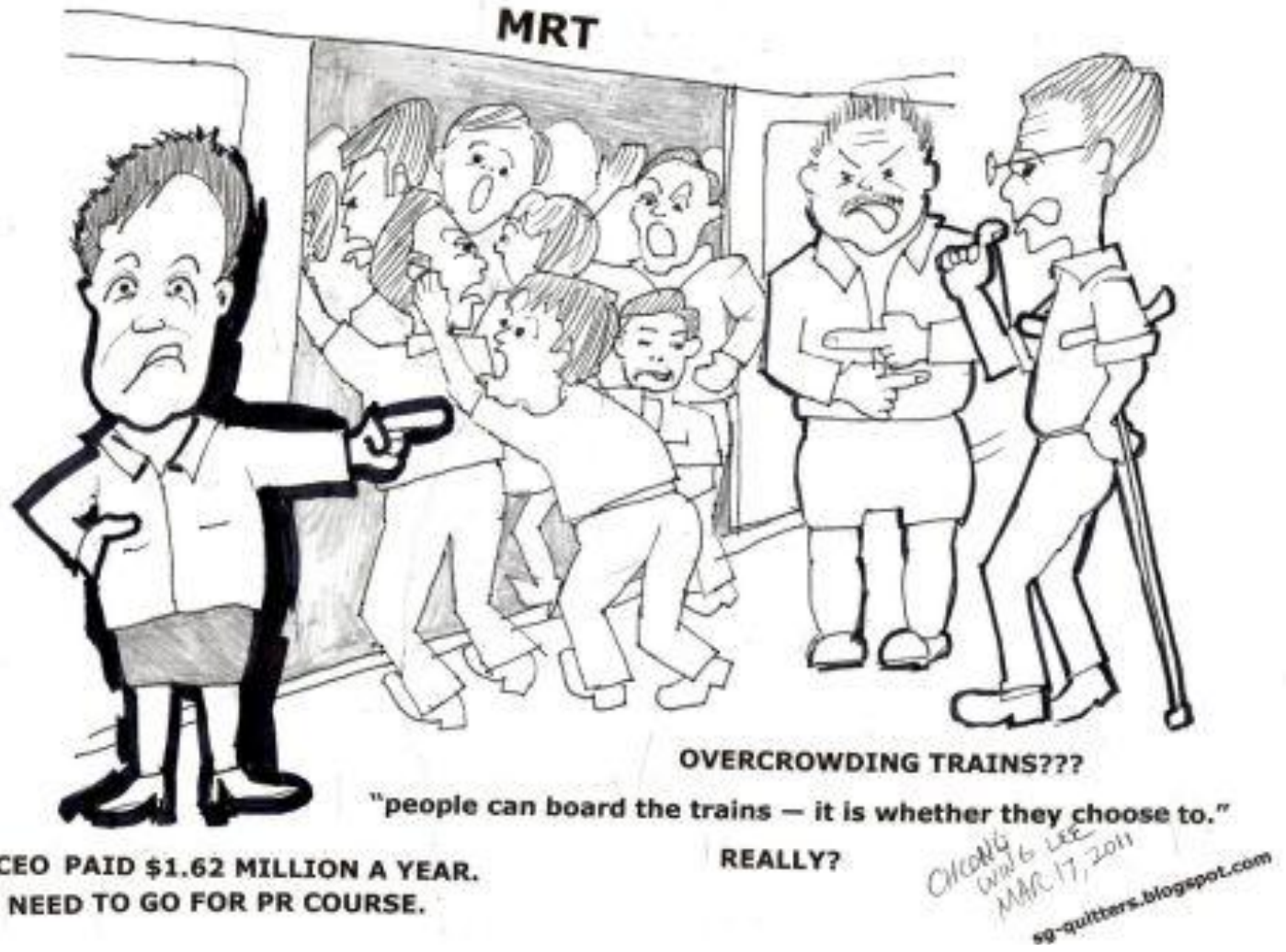

Figure 3. A "demotivational poster", parodying the words of SMRT CEO Saw. (2011).

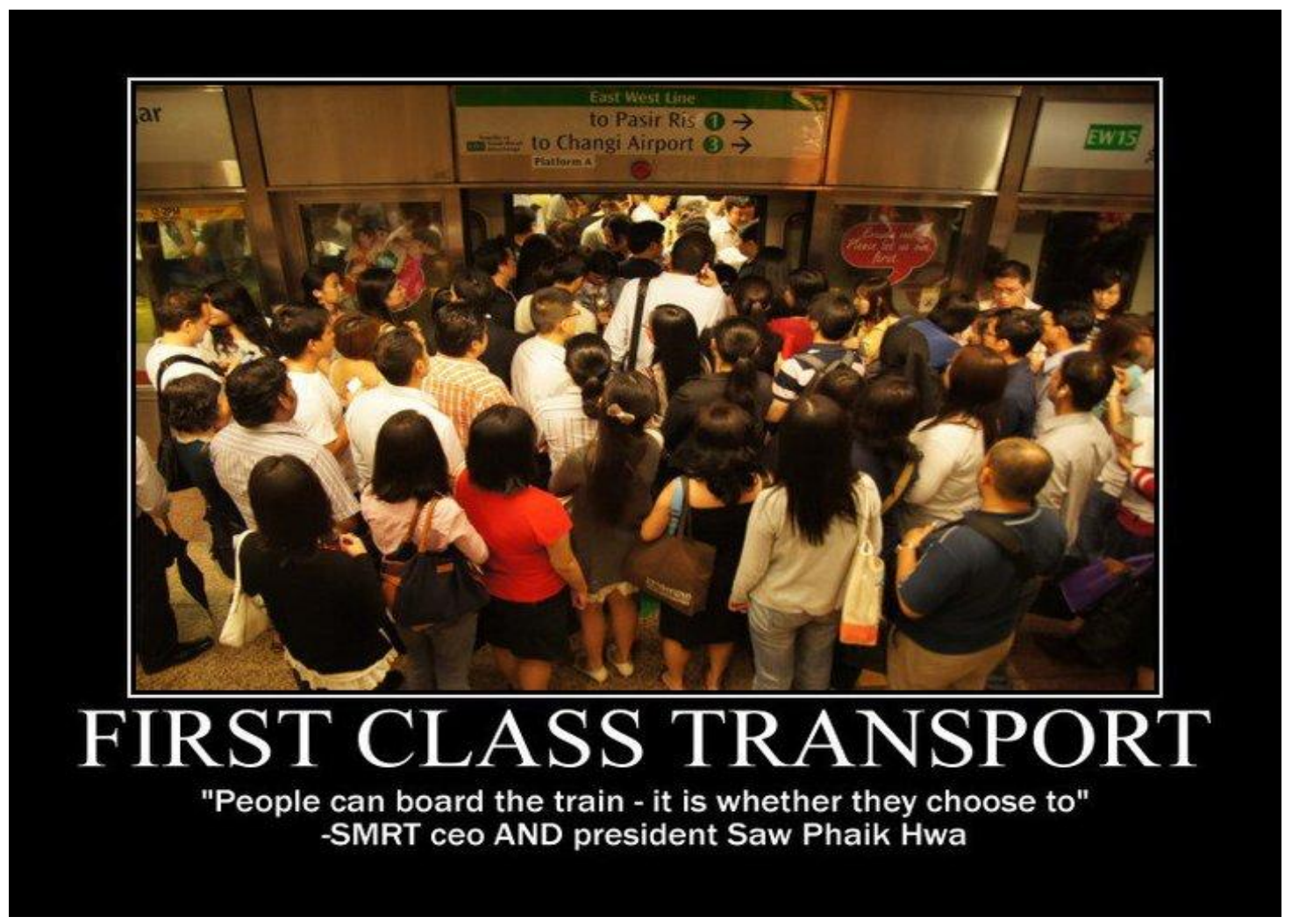

Open-access journal | EJHR: www.europeanjournalofhumour.org 


\subsubsection{Train breakdowns}

The straw that broke the camel's back happened on December 2011 when two major breakdowns occurred within two days of each other, leaving thousands of commuters stranded (Saad 2011). This was then followed by more minor breakdowns, which continued to disrupt train travel (Ramesh \& Soh 2011). The timing of these major breakdowns was particularly unfortunate for SMRT as the transport company, together with other operators, had just successfully applied to the Land Transport Authorities for an increase in their fare several months earlier amidst fierce objection online. This increase "of 1 percent will mean that the transport operators stand to gain \$15 million in extra revenue" (Mokhtar 2011). Commuters felt the increase was unjustified as the company had already been posting extremely healthy profits while the quality of service they have been providing was perceived as either stagnant or deteriorating. One anonymous blogger who calls herself "Singapore Election" noted that SMRT's percentage of profit after tax against revenue from 2006 until 2010 has been consistently high, making SMRT " 8.3 times more profitable than SIA" (SIA is Singapore Airlines, the national flight carrier and pride of the nation). The blogger's analysis is represented in Table 1.

\begin{tabular}{ll} 
Year & Profit in percentage \\
\hline 2006 & $14.5 \%$ \\
2007 & $18.2 \%$ \\
2008 & $18.7 \%$ \\
2009 & $18.5 \%$ \\
2010 & $18.2 \%$ \\
\hline
\end{tabular}

Table 1. SMRT Profit in percentage from 2006-2010 (Based on http://singaporeelection.blogspot.sg/2011/08/sbs-and-smrt-more-profitable-than-sia.html)

\subsubsection{Public relations faux pas}

On 14 December 2011, when a breakdown occurred during the morning rush hour, Hossan Leong, the actor-singer-DJ, immediately reported it in his morning radio show, advising his listeners to find alternative means to get to work. His information was based on comments received in his Twitter account. However, he was immediately "censured for announcing the disruption to the Circle Line train services" because "his announcement came before an official statement was released by SMRT" (Cai, 2011). Fans and sympathisers of Leong were angered by the high-handed attitude of the authorities (it was not known if the censure was from SMRT or the radio station itself) who they perceived as having been not only unhelpful in alleviating the woes of the travelers by providing timely announcements and travel advice, but are now taking an unduly hard stance against a helpful a well-meaning person who stepped in to fill in the information gap where the authorities have failed. They responded by immediately spreading jokes targeting SMRT online. These primarily took the forms of comments and postings in social media like Facebook and Twitter.

When the train broke down again in the evening of 15 December passengers of the stranded train were stuck in the tunnel for close to an hour. Passengers alleged that the train driver did not know what to do and they had had to remain in a carriage that had no lights or ventilation as the power had been cut. After some time, some passengers were reported to have experienced difficulty in breathing which prompted one male passenger to make the drastic decision of breaking a glass window of the door with a fire extinguisher. Photos of the condition in the train during that episode taken by passengers using their smartphones were 
circulated almost immediately. However, SMRT subsequently denied that the trains had no power and countered the news by insisting, against the photo evidence online (Figure 4), that "passengers affected by Thursday's train breakdown should not have been gasping for air or been plunged into darkness even if they were trapped in a stalled train" because "[w]hen a train loses its power and stops on the tracks, an emergency power system should kick in" ("MRT breakdown: Emergency power should have kicked in" 2011).

Figure 4. A photograph posted by a passenger trapped in the tunnel during the breakdown (Source: "MRT breakdown: Emergency power should have kicked in”2011).

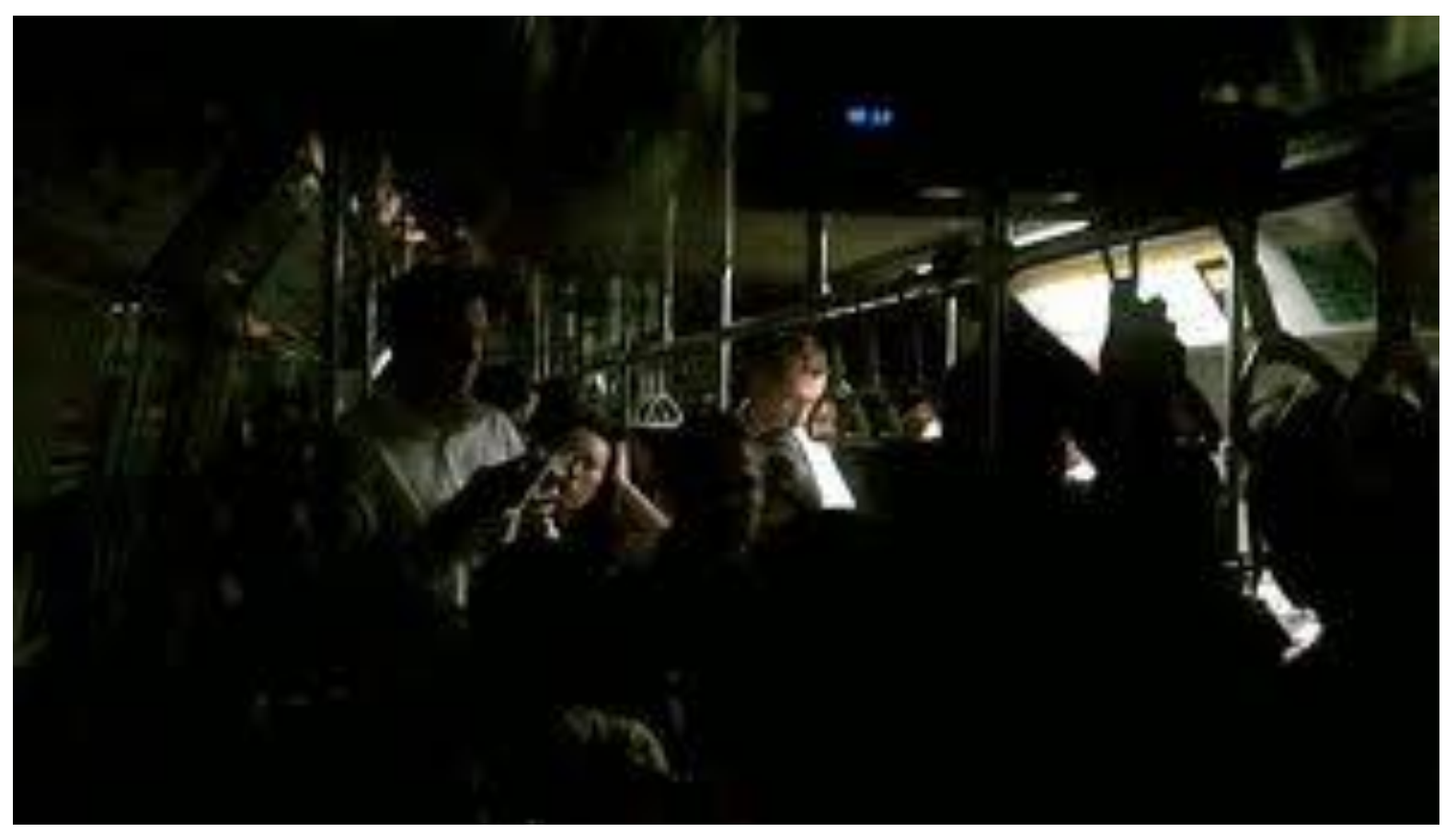

SMRT subsequently issued an advisory urging commuter to "never smash the windows or force the doors open" ("MRT breakdown: Don't break the windows, says SMRT" 2011). The advisory ended with the statement "He [the man who broke the window] should not have done so but considering the situation, he will not be penalised, SMRT officials said". This earned SMRT further ridicule from Twitter users like@benjubby 17 Dec 2011, 9pm: "Yea right. Like you just expect us to wait till we die" (2011).

\subsection{Netizens' responses}

In an unparalleled burst of spontaneous creativity, and to a certain extent, boldness seldom seen in Singapore, (although most of the perpetrators nevertheless felt the need to remain anonymous), netizens seized upon a photograph published by The Straits Times Online of the broken window (see Figure 5) to express their ire. 
Figure 5. Screenshot of the original photo of broken window. (Source: "MRT breakdown: Don't break the windows, says SMRT” 2011).

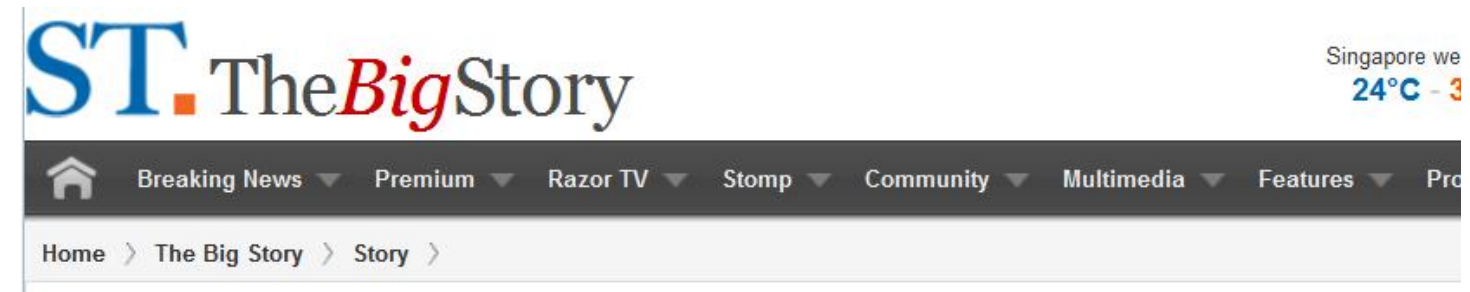

\section{MRT breakdown: Don't break the windows, says SMRT}

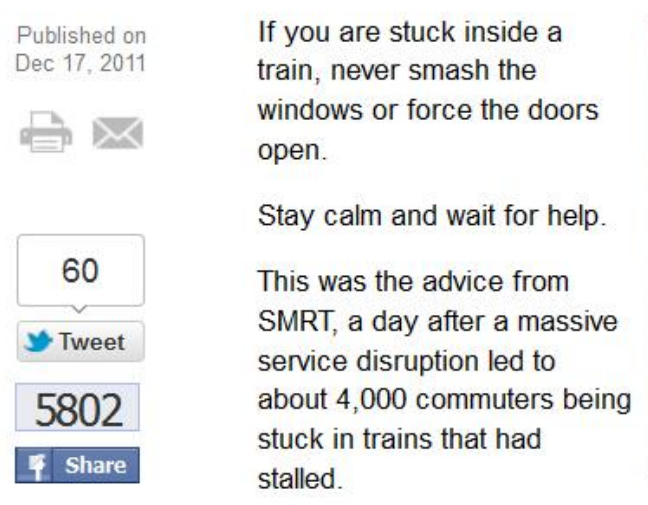

\author{
If you are stuck inside a \\ train, never smash the \\ windows or force the doors \\ open. \\ Stay calm and wait for help. \\ This was the advice from \\ SMRT, a day after a massive \\ service disruption led to \\ about 4,000 commuters being \\ stuck in trains that had \\ stalled.
}

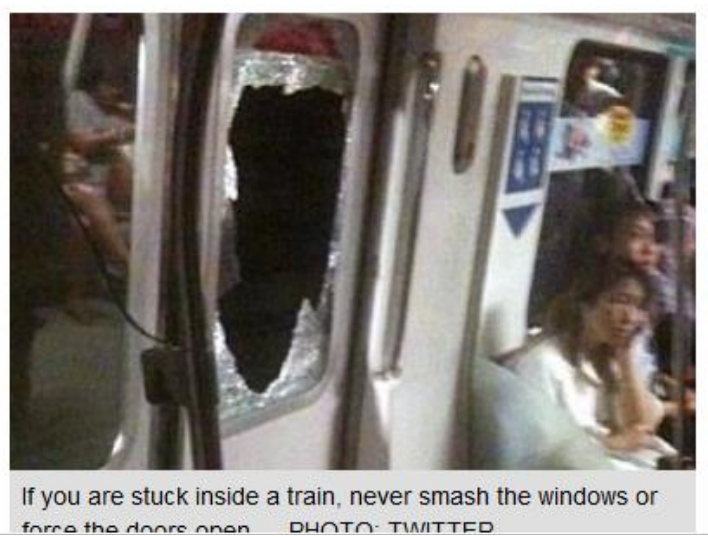

farrotho Hnnre nnon DHATA- TIMIITTED

By manipulating the photo digitally images were added to depict ridiculous explanations for the broken windows (see Figure 6, a to f). The technique used for these pictures is a simple superimposition of another image upon the original:

\section{a) "Angry Bird"}

(http://blog.omy.sg/cloudywindz/archives/996/mrt_breakglass1)

b) "Alien" from the movie of the same name

(http://blog.dk.sg/wp-content/uploads/2011/12/alien.jpg)

c) "Sadako" from the Japanese horror film "The Ring" (http://blog.omy.sg/cloudywindz/archives/996/mrt_breakglass3)

d) Abercrombie and Fitch photo of a model taken from a recent controversial launch of the company's Singapore outlet when a giant poster of a naked male torso hung outside its new building offended the sensibilities of certain quarters and had to be taken down. During the launch topless male models cavorted with the customers who queued in long lines to have their picture taken together.

(http://www.stomp.com.sg/isayyousay/images/20111226/20111226grace\%20\%2811\%29 .jpg)

e) Leonidas from the movie " 300 "

(http://www.asiaone.com/static/multimedia/gallery/111209_mrtspoofs/images/pic7.jpg)

f) The Incredible Hulk (http://blog.dk.sg/wp-content/uploads/2011/12/Hulk.jpg) 
European Journal of Humour Research1(2)

Figure 6, a) to f) Netizen's doctored photographs of the broken window.

a)
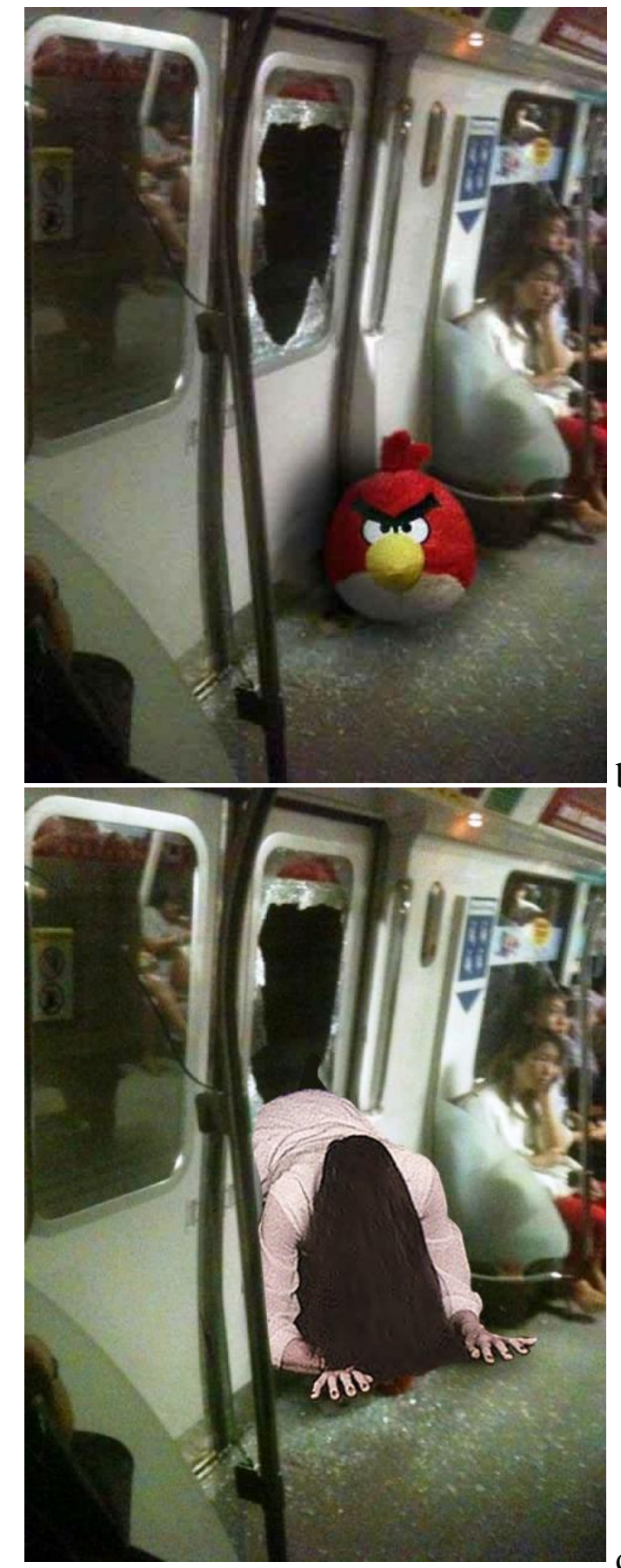

b)
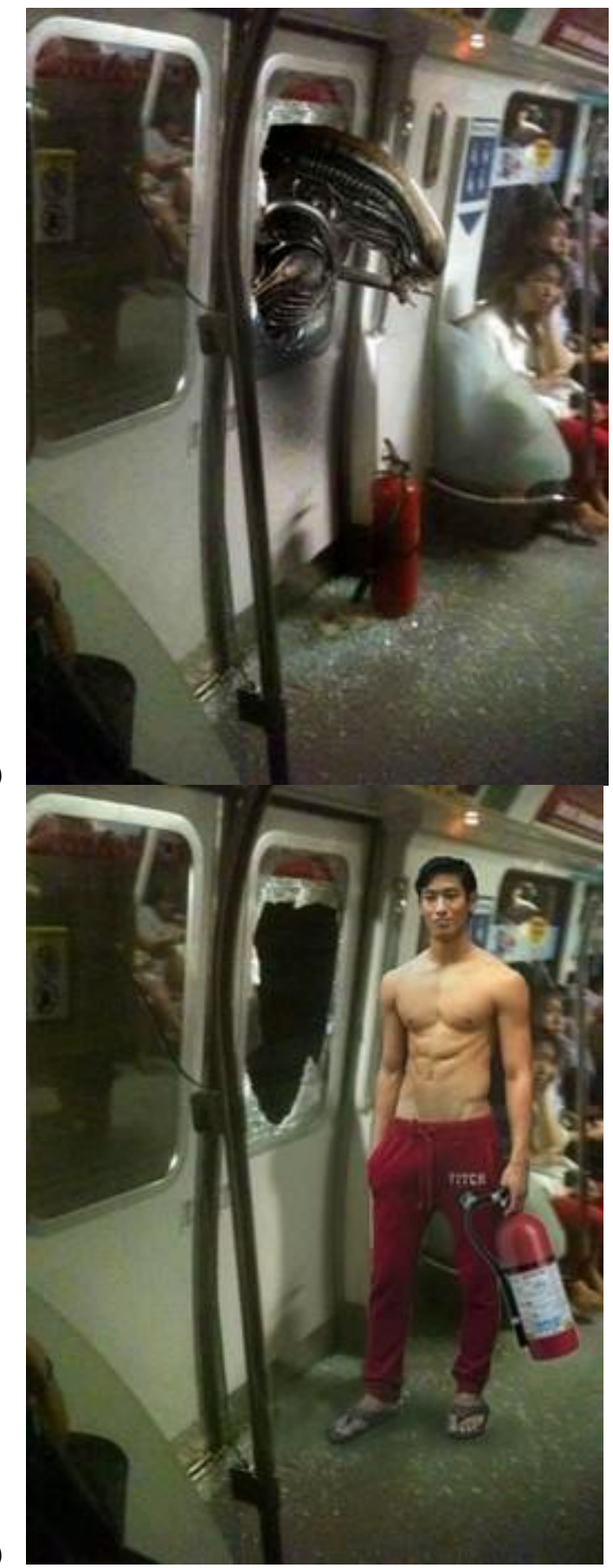

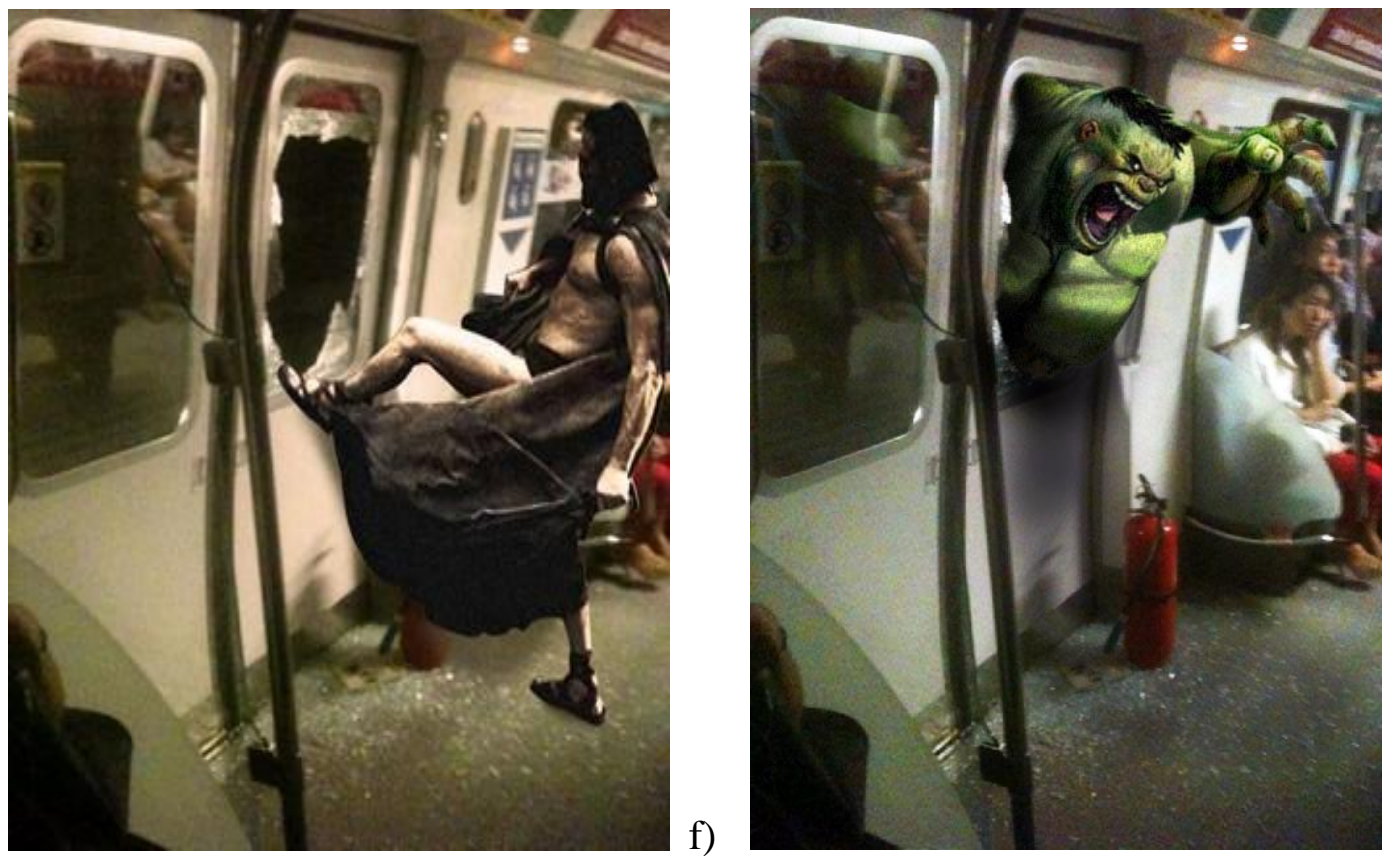

e)

A couple of memes used a slightly different technique. One was a parody of SMRT's own publicity poster (Figure 6g).

Figure 6g. A parody of SMRT's promotional poster.
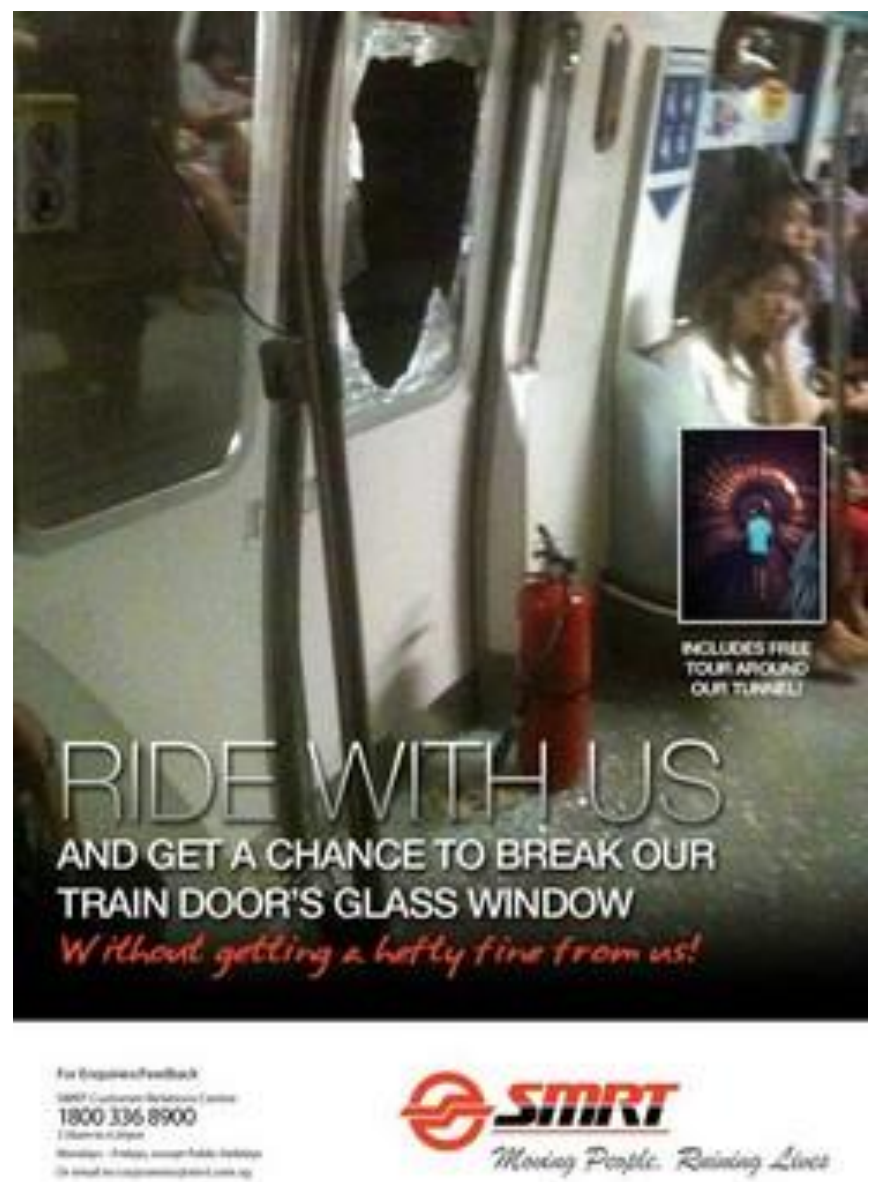
Figure $6 \mathrm{~h}$ is a parody of Time magazine suggesting that the person who broke the window ought to be hailed a hero instead of the suggestion by SMRT that he was a vandal.

Figure 6h. Parody cover of Time's person of the year.

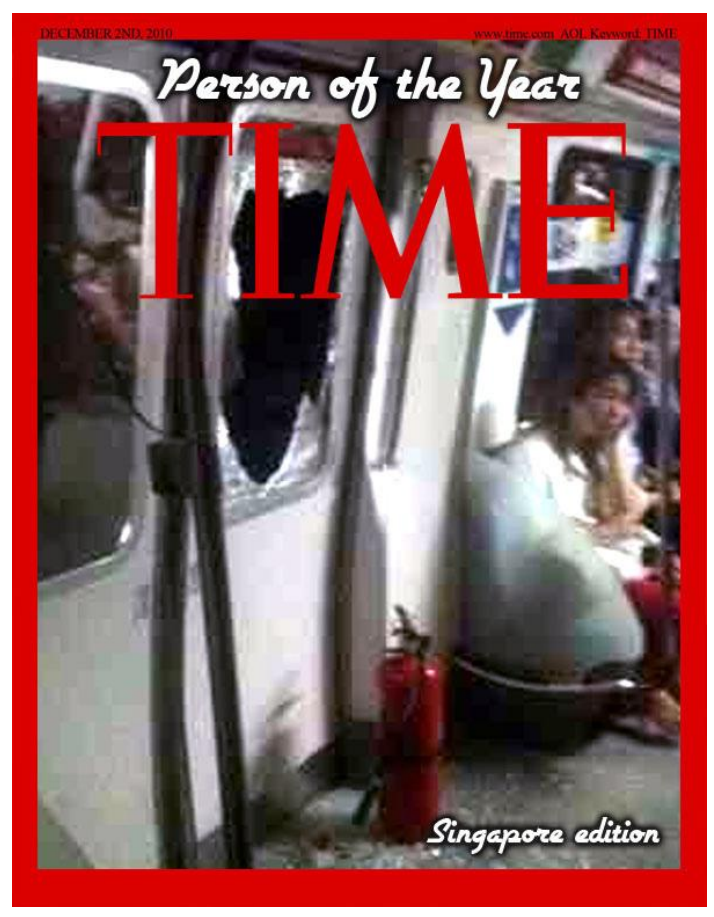

CEO Saw Phaik Hwa quickly became the target of scorn. A demotivational poster, a parody of the motivational poster, depicted her issuing a challenge à la Dirty Harry's "go ahead, make my day" to the public to break her windows. It was framed in typical Singapore colloquial English: "Break my MRT window. Break lo. I increase fare only, wahaha!" (Figure 7a). The Singlish article $l o$, more normally spelled as lor, is borrowed from Cantonese and functions as an marker to denote resignation or dismissiveness. Another demotivational poster labeled her as an outright failure (Figure $7 b$ ).

Figure 7a. Demotivational poster depicting CEO Saw challenging the public to break her train windows. (Source: Anonymous X 2011).

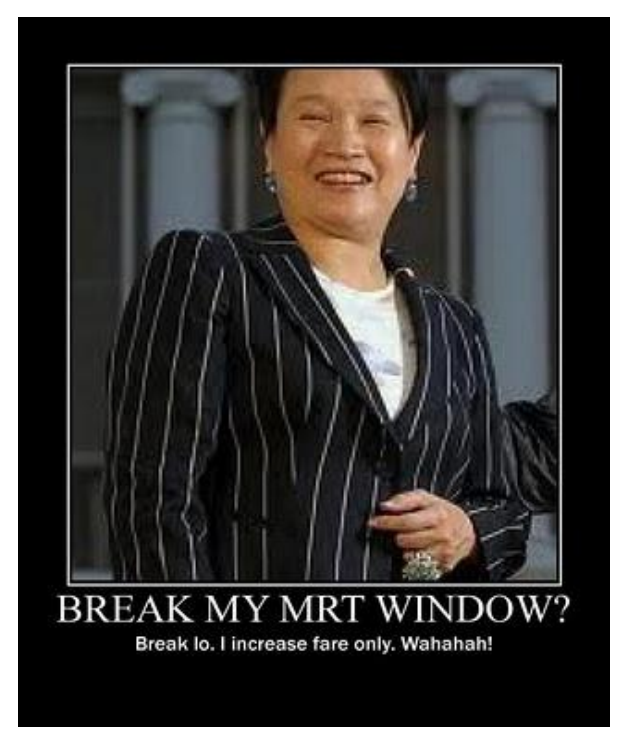


Figure 7b. SMRT CEO Saw Phaik Hwa labelled as a failure (Source: "SMRT CEO gets her own Failure Demotivational Poster" 2011)

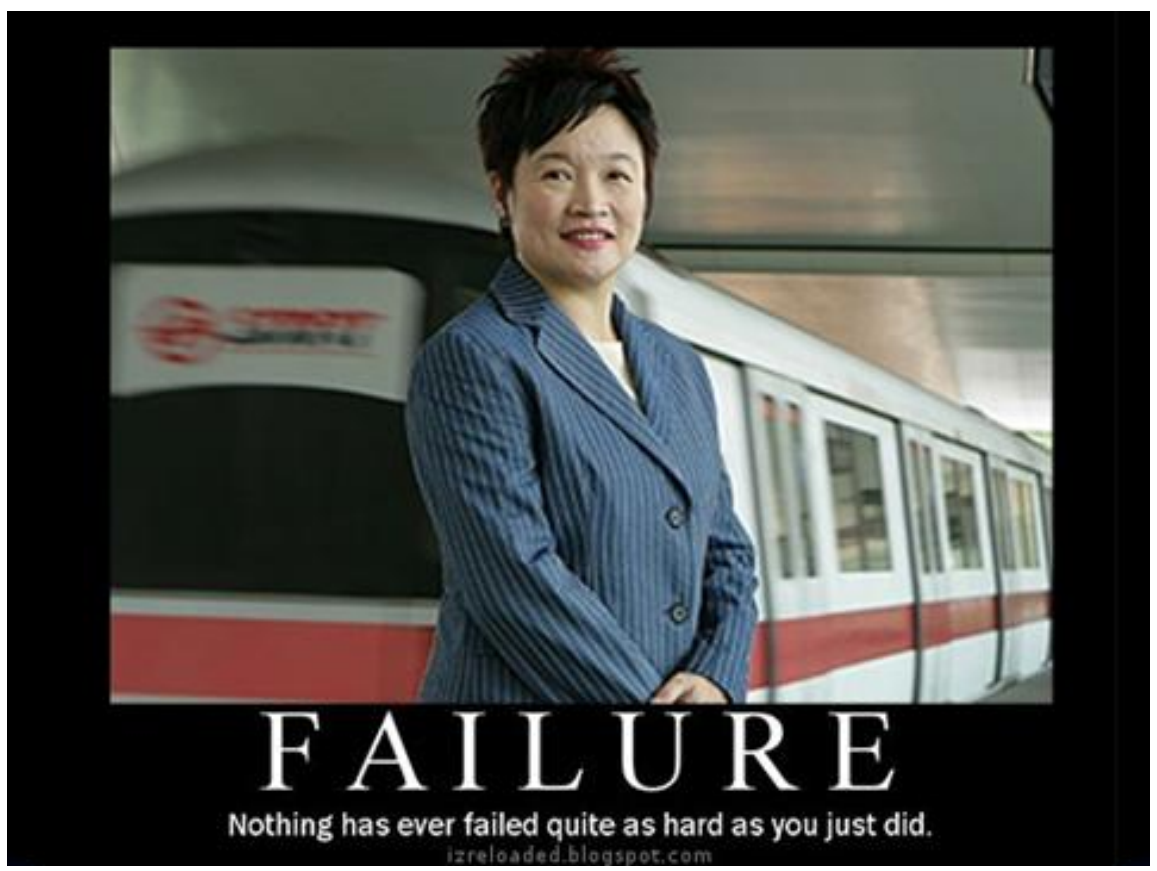

At Hong Lim Park, Singapore's one and only government-sanctioned speaker's corner, a group had gathered to call for the CEO's resignation ("SMRT president in the hot seat" 2011). One poster held up by the protesters had a clever wordplay on the SMRT abbreviation "SMRT: Saw Must Resign Today" (Figures 8a \& 8b). The photograph of this poster was quickly circulated on the Internet.

Figure 8a. Saw Must Resign Today. (Source: AsiaOne 2011).

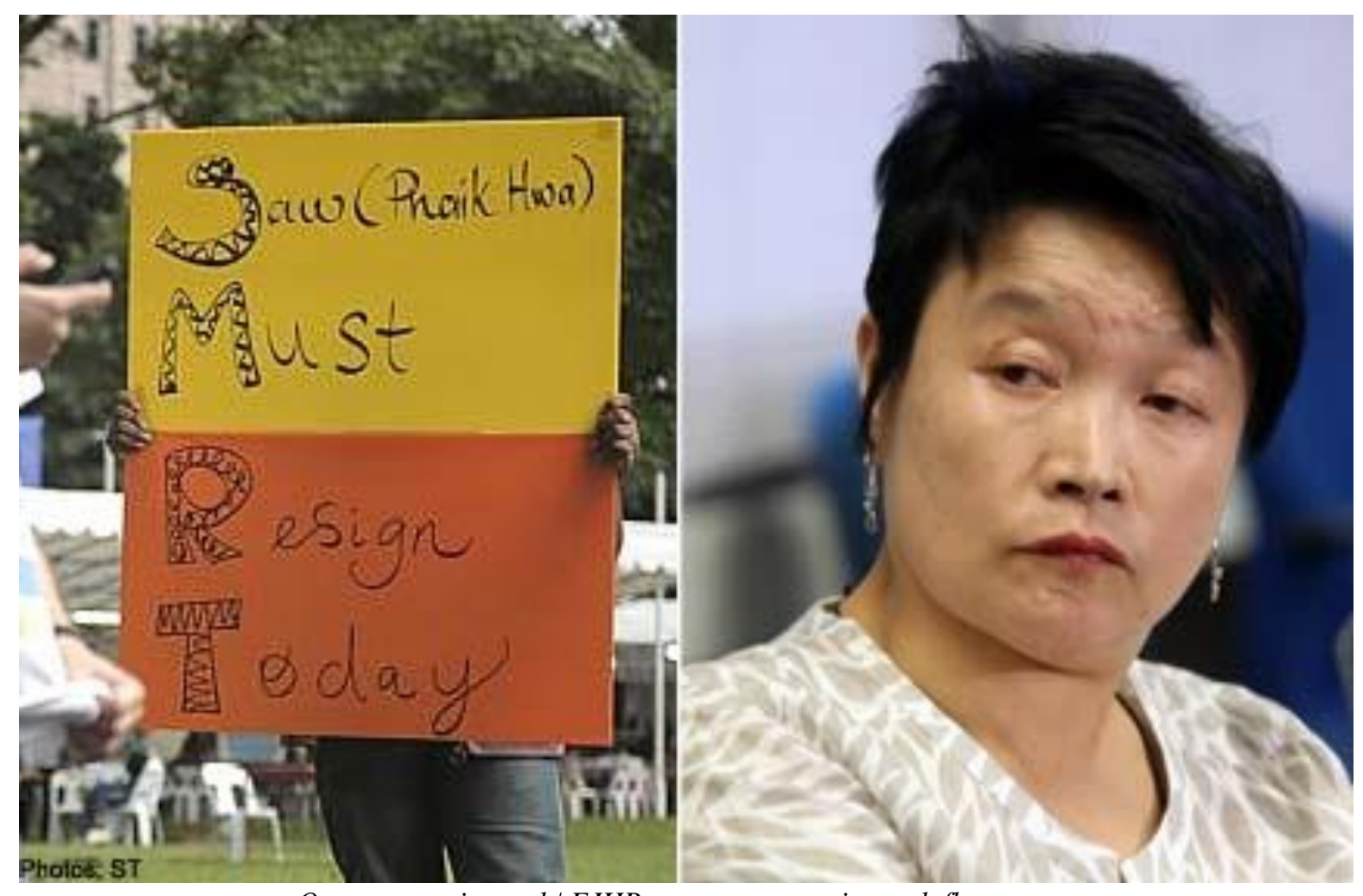

Open-access journal | EJHR: www.europeanjournalofhumour.org 
Figure 8b. A group of protester at Hong Lim Park, expressing their displeasure at the SMRT service interruptions. (Source: Unknown)

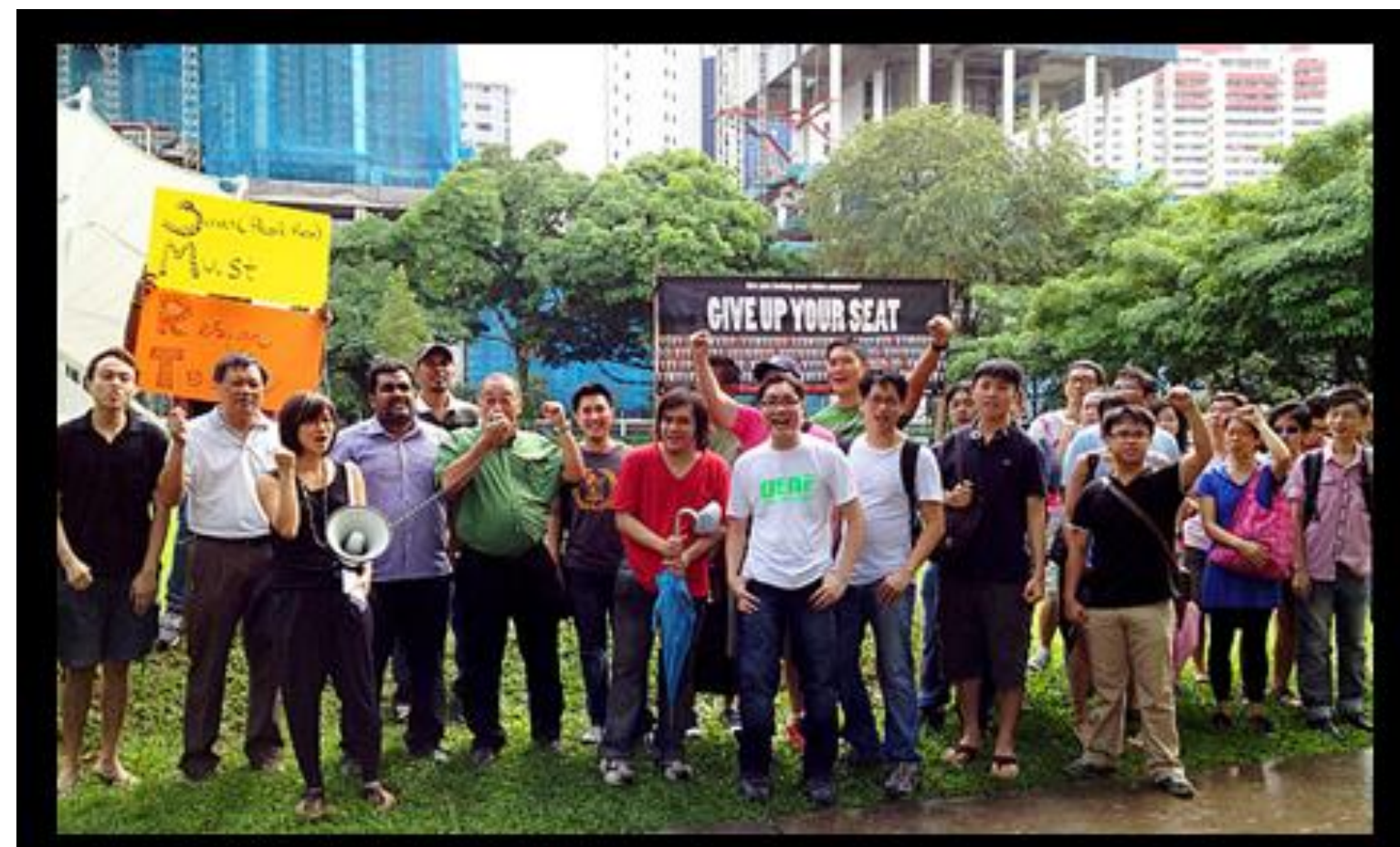

Sat, Dec 17, 2011

Saw, however, resisted the suggestion and in a press conference stated that "she has no plans to step down over the disruptions" because in her opinion "being responsible does not mean walking away, instead it means doing all she can to get the problem fixed" ("SMRT CEO not stepping down" 2011). This announcement immediately drew more criticisms online, with some portraying her as a ruthless corporate tyrant bent on keeping her high paying job. A photo of a past Egyptian-themed SMRT corporate annual dinner, in, which Saw was carried on a sedan chair by a group of topless young men, found its way to the Internet (Figure 9a) and immediately went viral. Soon after, the theme was picked up by other Internet users who again using image manipulation, depicted her as Cleopatra lording over her minions (Figure 9b). 
Figure 9a. The SMRT Egyptian themed annual dinner photograph. (Source: "SMRT CEO dressed up as 'queen"' 2011).
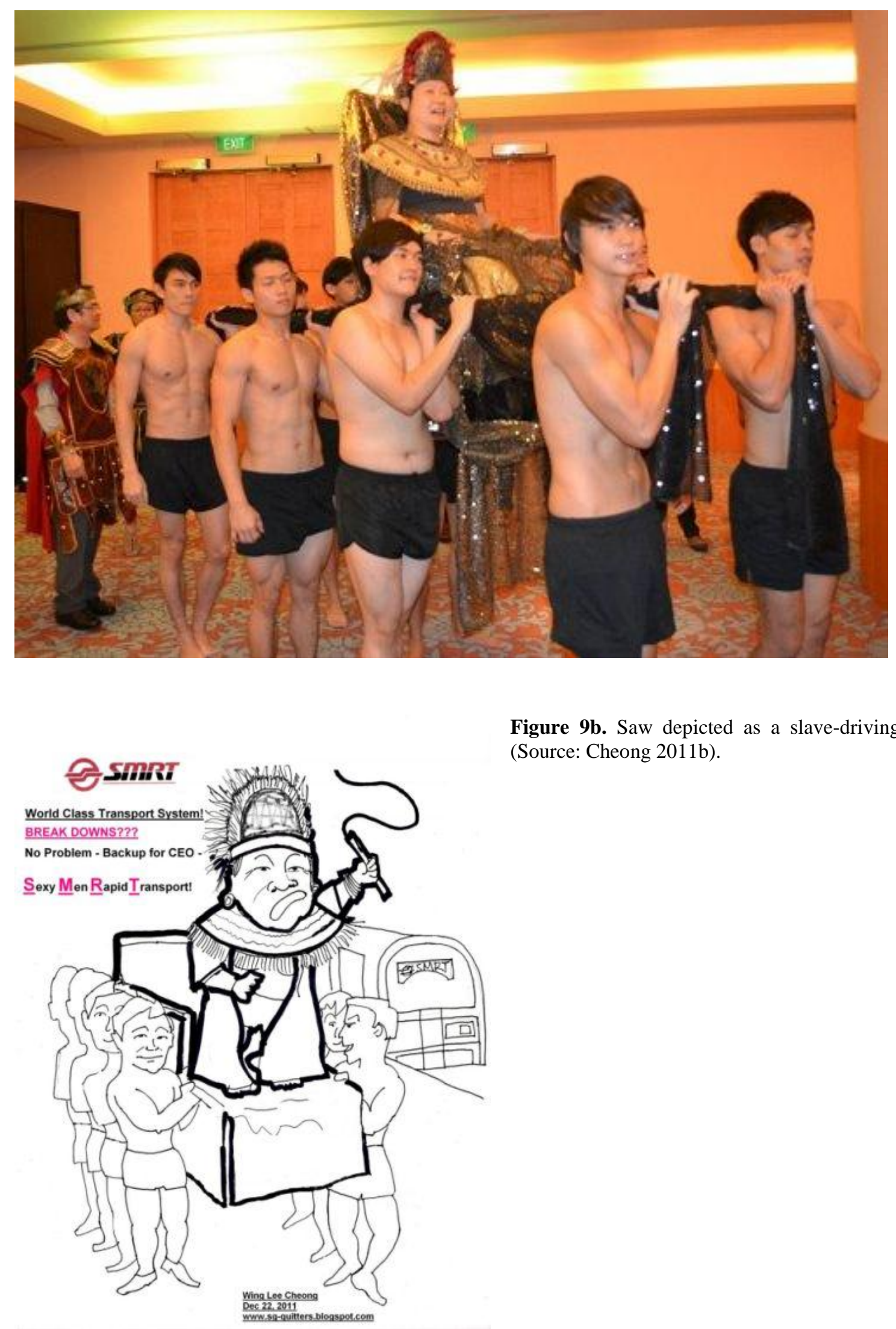

Figure 9b. Saw depicted as a slave-driving tyrant (Source: Cheong 2011b). 
One anonymous user then created a template from this annual dinner photograph and placed it at ImageShack (n.d.) to be made available for anyone who wished to create their own version of the image. (The link has since expired but the template can be viewed in Figure 9c.)

Figure 9c. SMRT annual dinner template (Source: ImageShack n.d.)

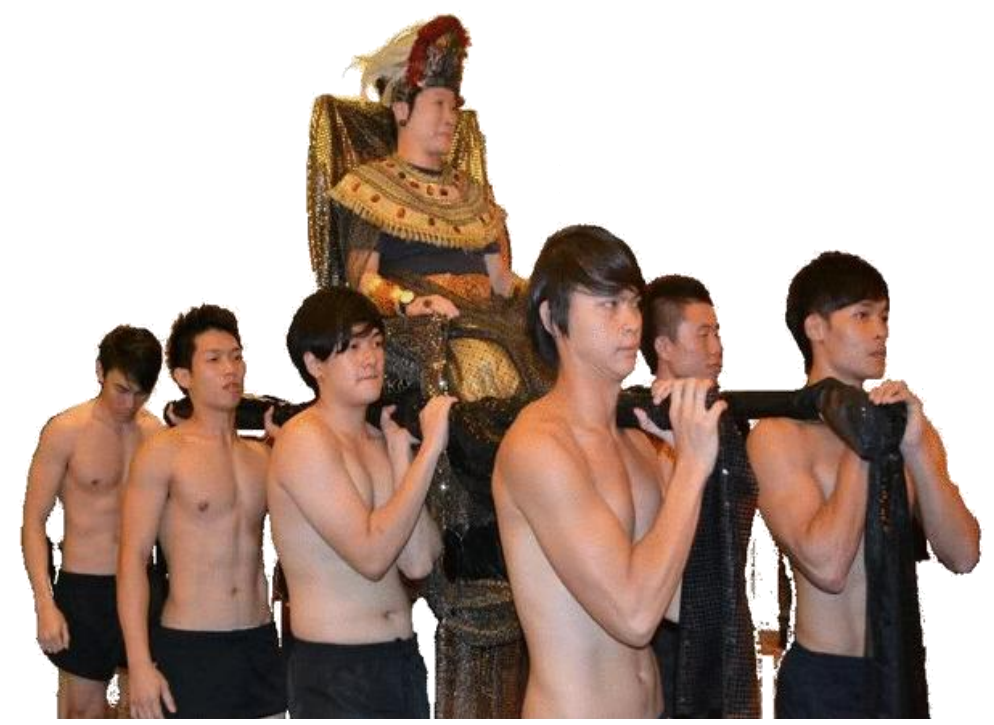

Many users then superimposed the template onto various scenarios, beginning with the obvious one of Saw touring Egypt (in line with the Cleopatra theme), gradually leading to more and more bizarre examples, as exemplified by the images listed here:

Figure 10a. Saw visiting the pyramids (Source of photo: http://farm8.staticflickr.com/7013/6548252395_110ef5ee09_z.jpg).

Figure 10b. Saw escaping the inconvenience of the MRT breakdown (Source of photo: http://farm8.staticflickr.com/7035/6548252209_ae73654f31_z.jpg).

Figure 10c. Saw gloating over the "peasants" (i.e. the commuters) who have to queue for the emergency shuttle buses during the breakdown, unlike the minority who can afford their own private modes of transportation. Singaporeans perceive a widening social gap between the "elites" and the "peasants" and feel the "elites" do not empathise with their daily inconvenience and struggles (Fong 2012). (Source of photo: http://farm8.staticflickr.com/7149/6548252097_4826ea21ed_b.jpg)

Figure 10d. Saw being carried through the MRT tunnel, leading the commuters in their evacuation. It was a sore point for the commuters who were stuck in the trains for up to an hour that they had to make a trip out of the trains onto the tracks to access the station. (Source of photo: http://farm8.staticflickr.com/7172/6548251633_68639c475e.jpg).

Figure 10e. Saw inspecting the MRT tunnel (Source of photo: http://farm8.staticflickr.com/7010/6548251993_e60332c2b4.jpg).

Figure 10f. Saw inspecting the graffiti on the trains. This picture aludes to the security lapse that occurred the several months ago. (Source of photo: http://farm8.staticflickr.com/7149/6548251723_12708fd83e_z.jpg).

Figure 10g. Saw touring the shopping district of Orchard Road. This can be interpreted as a swipe at her high paying job and lavish lifestyle, and also her background in the retail sector. Critics attributed the SMRT failure to her appointment as CEO because she was formerly the CEO of DFS, a retailer of luxury goods, which targets travellers ("About DFS" 2012) and have no engineering qualification or experience in running a transportation company. (Source of photo: http://farm8.staticflickr.com/7172/6548251279_7ff7557245_z.jpg). 
Figure 10h. Saw inspecting Kim Jong Il's body. The North Korea leader died on Dec 17, the same day as one of the breakdowns (Williams 2011) (Source of photo: http://farm8.staticflickr.com/7011/6548252295_b64976a475_z.jpg). Figure 10i. Saw recruiting the teddy bear-like Ewoks from the Star Wars movie to make the repairs (Source of photo: http://farm8.staticflickr.com/7032/6548251817_373455837d_z.jpg). Figure 10j. Saw evading the road tolls (ERP) of Singapore's expressways in her sedan chair. The allusion is to the government's justification of prohibitively high taxes for cars and a road usage toll to force Singaporeans to use public transportation instead. (Source of photo:

http://multimedia.asiaone.com/A1MEDIA/multimedia/12Dec11/others/20111224.143854_pic 1.jpg).

Figure 10k. Saw inspecting the SMRT buses. This picture alludes to an incident that occurred around the time of the MRT breakdown when a new bus driver was directed by the control station to divert to a different route to avoid a massive traffic jam. The driver, unfamiliar with the roads outside of his standard route got lost, resulting in the passengers being treated to a two-hour unsolicited joyride. Strict regulations prohibited the driver from allowing passengers to disembark anywhere other than the bus stops designated for the route service. (Source of photo: http://farm8.staticflickr.com/7002/6548251545_b60c9e8bf9_z.jpg).

Figure 101. Saw walking to the edge of a waterfall with the caption "Final Destination", the name of a series of movies of the same name, possibly symbolically predicting her career's demise or worse (Source of photo:

http://farm8.staticflickr.com/7005/6548251911_303292d8dc_z.jpg).

Figure $10 \mathrm{~m}$. The humour makes a poetic full circle back to the first broken window meme with Angry Birds. The caption suggested that Saw angered the Angry Birds, which was why one was projected through the window. (Source of photo:

http://farm8.staticflickr.com/7175/6548251111_efa17a4a11_z.jpg).

Figures 10 a - m. Samples of the Internet memes mocking Saw, CEO of SMRT.

a) The original template

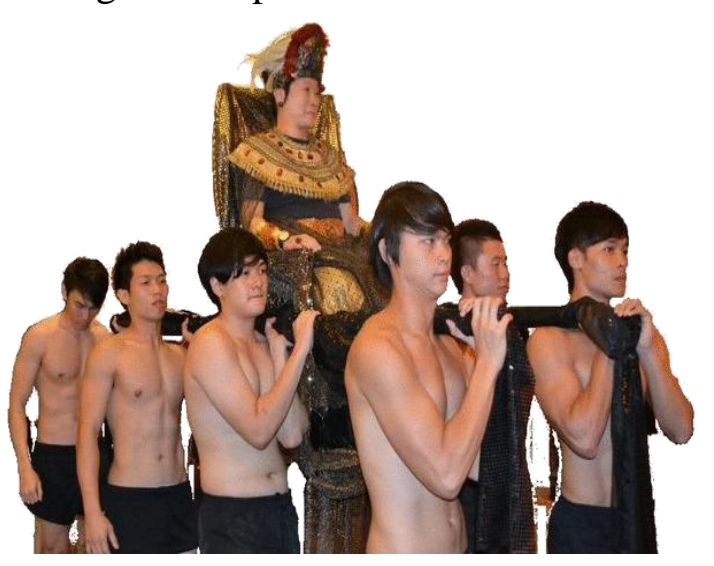

c) "Train Disruption? It's okay, if you have your own entourage of muscled slaves to carry you around" b) Saw visiting Egypt

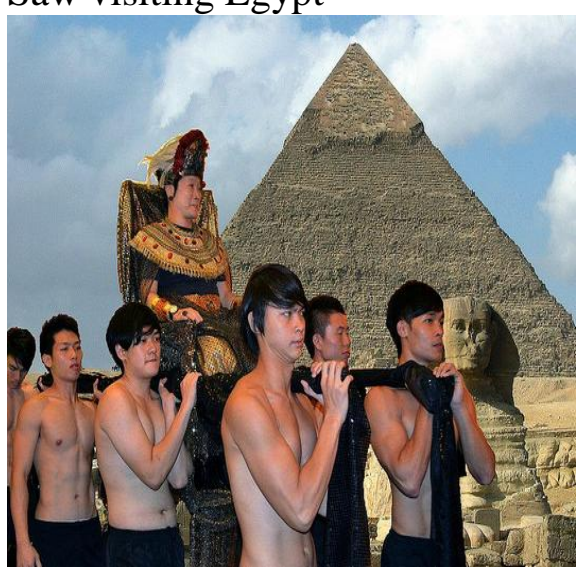

d) "Inspecting poor peasants who have to queue to board SMRT shuttle buses after train breakdown" 
European Journal of Humour Research1(2)
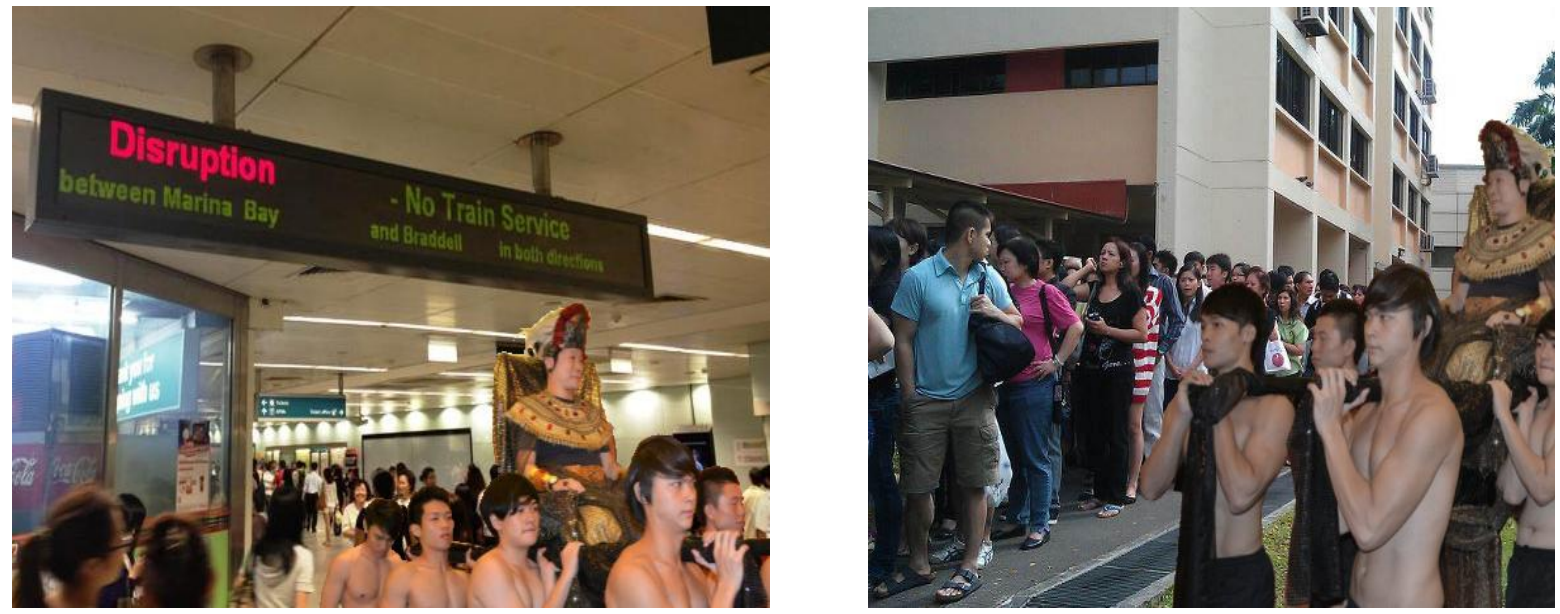

e) "Embarking on a SMRT tunnel walk"

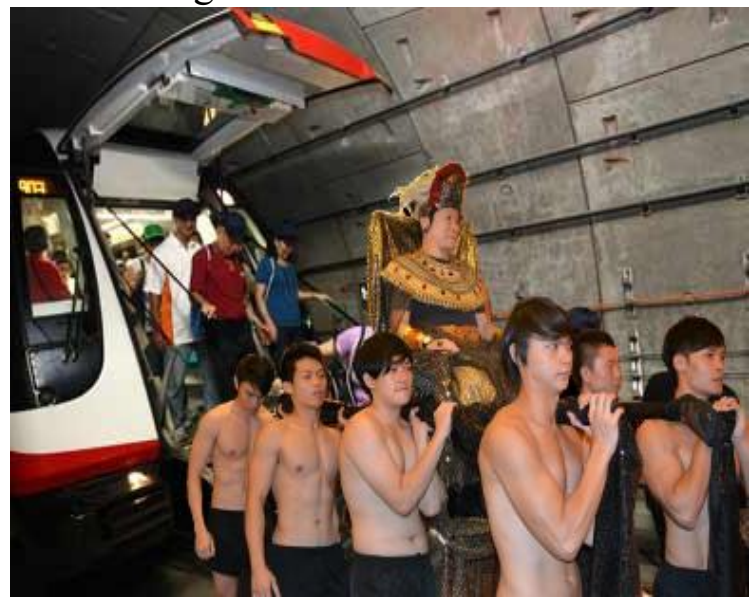

f) "Inspecting SMRT tunnel"

g) "Inspecting the beautiful free graffiti on SMRT train"

h) "Shopping at Orchard Road"
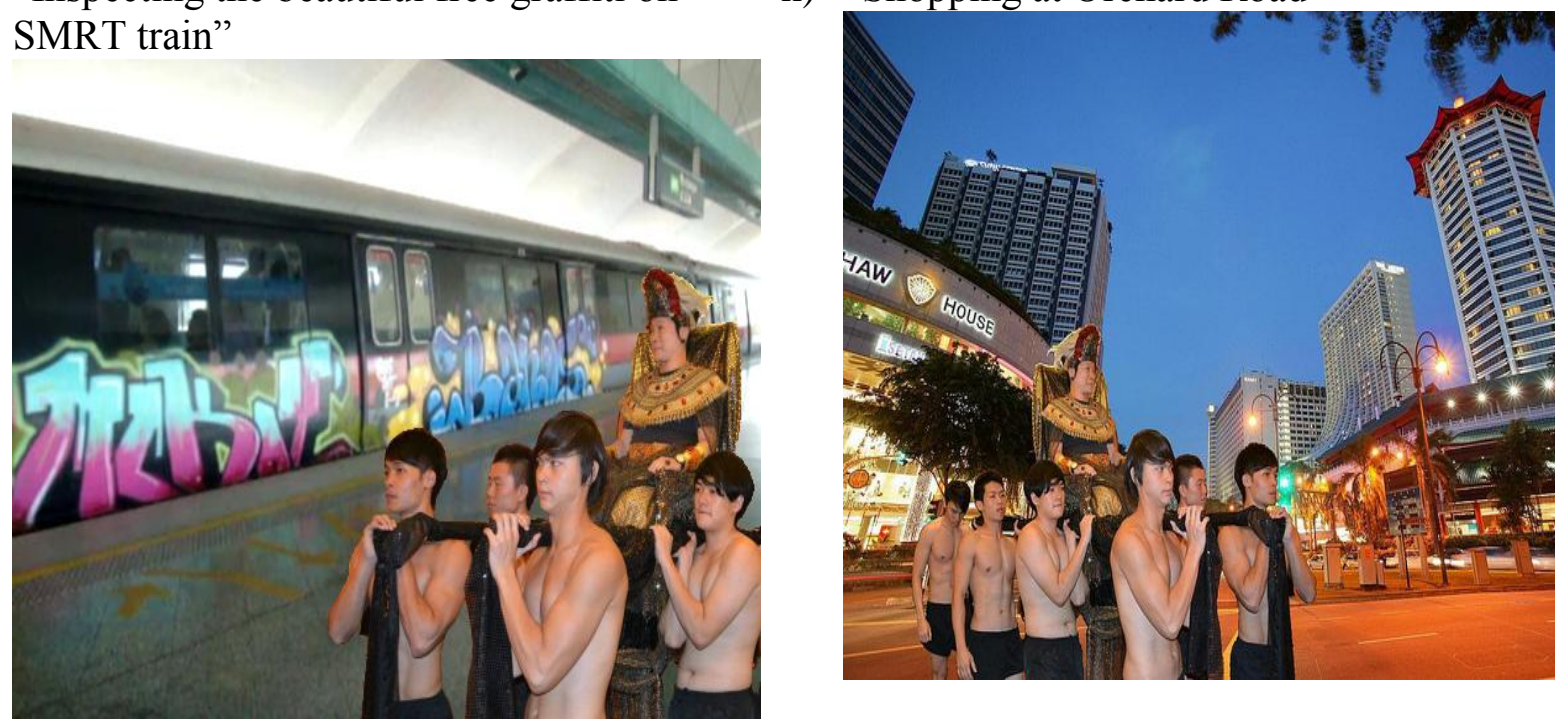

i) "Inspecting Kim Jong Il's dead body"

j) "Recruiting Ewoks to repair SMRT trains" 

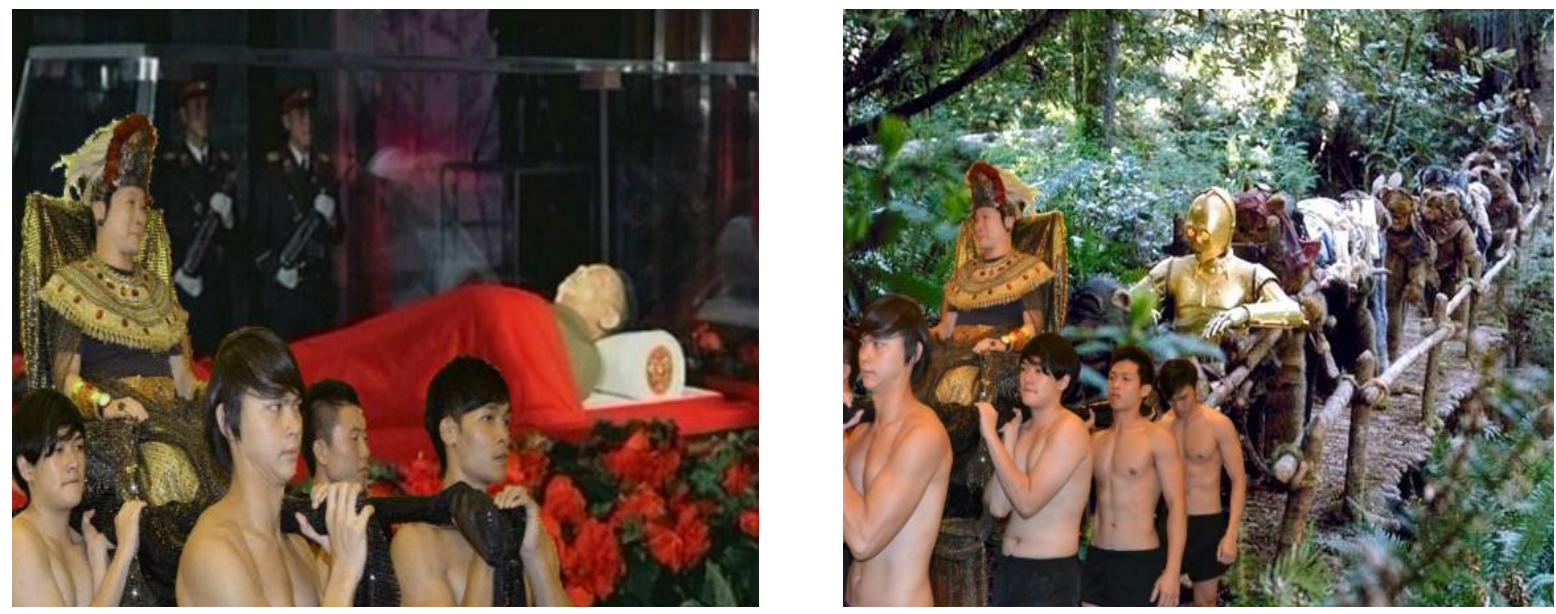

k) "The best mode of transport to evade ERP"

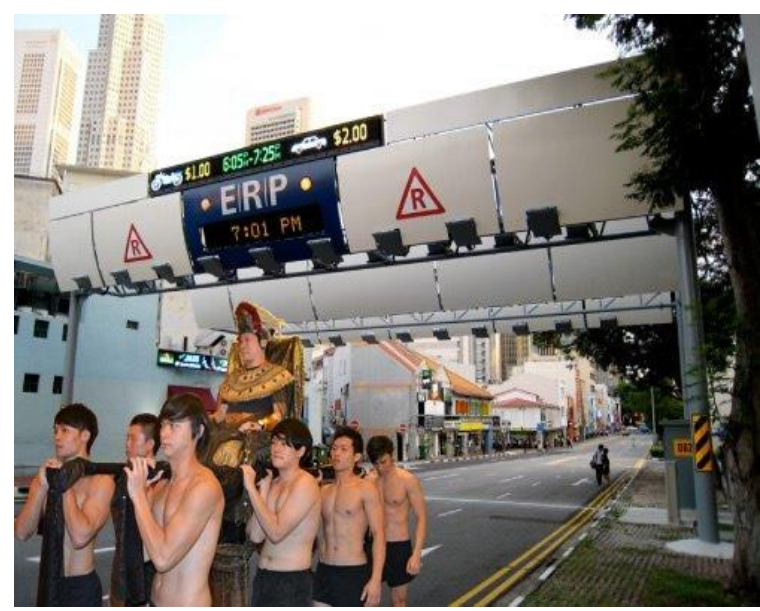

1) "Inspecting SMRT buses to ensure the drivers know their bus routes"

m) "Final Destination"

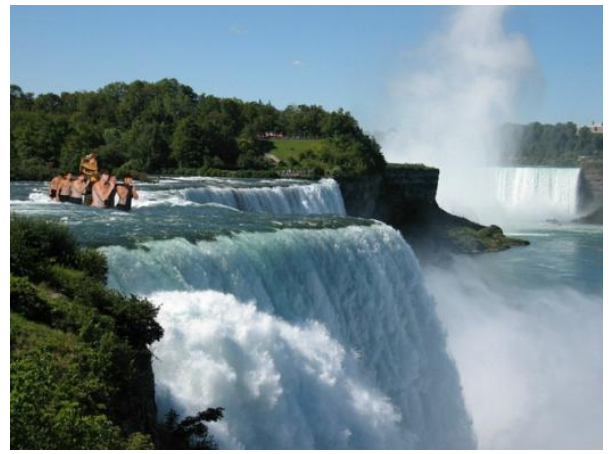

n) "How Saw made the Angry Birds angry..."

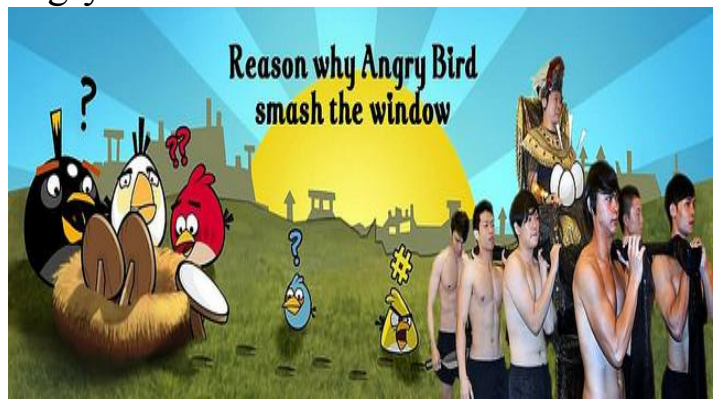

Despite her earlier words of defiance and denial of the possibility of resigning, less than a week after the New Year she capitulated and announced her resignation in January 2012 (“SMRT CEO Saw Phaik Hwa resigns” 2012).

\section{Discussion}

The SMRT debacle is both interesting and unique for a number of reasons. Singaporeans are normally politically placid and unwilling to express their unhappiness in the public space, 
preferring to swallow their socio-political misery and live and let live. Part of the reason is because the general public have hitherto not had real access to the public sphere. Habermas (1991 [1962]: 1-2) in his seminal study, The Structural Transformation of the Public Sphere, explained that the word "public" has evolved over time and is very much dependent on the context of the word in use. His idea was that when "we call events and occasions 'public' when they are open to all, in contrast to closed or exclusive affairs - as when we speak of public places and public houses but as in the expression 'public building', the term need not refer to general accessibility; the building does not even have to be open to the public traffic". This is particularly descriptive of the public sphere in Singapore where the publicness is colonised by the mainstream media controlled by the government. The use of "public sphere" in Singapore does not have much affinity to the common meaning of public as in public opinion or public outrage. Today's media scholars (Gimmler 2001; Papacharissi 2002; Castells 2008) are monitoring closely the promise of the Internet to provide an alternative public sphere, one that is no longer in any single group's control over public debate but one that is truly public in the common sense, possibly transcending local, regional and even national boundaries; where negotiation of power relationships can take place between the disparate voices of the various stakeholders of any particular issue.

The lack of access to the public space notwithstanding, during the rare times when their discontent boils over and when the Singapore public do make their voice heard, never have they progressed to the point of baying for blood like in this episode with SMRT. The most famous example of this hesitancy in recent years would be opposition leader Low Thia Khiang in parliament when debating the shocking escape of terrorist suspect, Mas Selamat from police custody, which turned the entire country into a large hunting ground. Despite their best effort, Mas Selamat's recapture eluded the police and to their great embarrassment, he was subsequently recaptured by the police in neighbouring Malaysia where he was holed up in a small obscure village. In parliament, Low had called for the same standard of accountability from the government as is practised in the private sector, vis-à-vis the "rolling of heads" of those in charge, including the CEO (firephoenix 1003 2008). The prime minister defended his deputy by saying that a line needs to be drawn as to how far up the hierarchy accountabilty should apply depends on the culpability of the various people in the chain of command and he then famously challenged Low (firephoenix 1003 2008) to make an outright call for the Deputy Prime Minister/Minister for Home Affairs, Wong Kan Seng, to resign, as the police falls under his ministry's purview. The PM's challenge was met with cowed silence from Low. This typifies the reluctance of Singaporeans, even the opposition leader, to push too hard for accountability from the ruling regime.

Although SMRT is not government-run, it is nonetheless government-linked, and without direct evidence of negligence on Saw's part, it is not unthinkable to pressume that she could have enjoyed the same level of immunity as DPM Wong if the same argument that Prime Minister used to counter Low the Mas Selamat case were applied. Furthermore, the SMRT CEO had already publicly declared her intention to remain in the driver's seat to fix the cause of SMRT's declining standard of service. So the question as to why she gave in to the pressure and resigned a couple of weeks later becomes pertinent.

The government has continued to maintain a strong grip over the mainstream media, and criticisms of the SMRT failures, although duly reported by the press, television and radio, were relatively mild. The media chose instead to focus on what the authorities are doing to set things right and what they intend to do to make things better in an obvious effort to control the damage. The bitterest criticisms then had to be expressed primarily through the social media network. However, the social network community consists primarily of a vocal minority of the "Western-educated" (Seah 2011). Seah also noted that the "Chinese-speaking heartlands" of Singapore are the traditional supporters of the establishment least likely to rock 
the boat so the pressure felt by the CEO is unlikely to be from them. Yet, the public opinion generated was sufficiently strong to, possibly for the first time in Singapore, result in the resignation of a public figure. It can be reasonably extrapolated that the negative public opinion was therefore likely to have been shaped by the minority English-speaking segment of the population.

Several hypotheses are worth exploring to explain this uncommon phenomenon.

\subsection{SMRT problem affected all segments of society}

No other issues in the past, including the dramatic escape of Mas Selamat, has had a direct effect on the populace. One reason for Singapore's politically sedate citizenry is because the government has always delivered on bread-and-butter issues and the attitude of the majority is that if things are not broken, no repairs are necessary. A report based on a study by The Institute of Policy Studies (IPS) confirmed that "a majority of Singaporeans prize economic growth over freedom of speech" (Chang 2011). However, the SMRT breakdowns constitute exactly the type of bread-and-butter issue that eroded this state of contentment. The vast majority of Singaporeans depends exclusively on the trains to get to work and school as they have few other alternative ways to do so. The bus service, although reliable, is slow and too time consuming. Taxis during peak hours are not easily available due to the high demand then. It is also relatively expensive for the lower income group, as peak hour rides are subject to a host of surcharges. As a result, the SMRT breakdowns were no longer a political issue solely in the domain of the outspoken Western-educated few who were often criticised as people opposing for the sake of opposing.

\subsection{The use of humorous visual images transcends language}

The novel way of employing an interactive form of visual art in a humorous way may have also contributed to this breakthrough in engagement of the silent majority, especially from the "Chinese heartlanders" referred to by Seah (2011). In the past, cartoons have been used by the opposition community but restricted to the blogosphere and never in the mainstream media. These were all done by professional artists or even amateurs who are fairly proficient at drawing, for examples Ben Soon (“Spore Says Political Cartoon” 2012) or Wing Lee Cheong (Cheong 2012). In the SMRT case Internet memes were employed instead. A very basic technique was used, namely the superimposition of one image onto another, as seen in the majority of the examples in Fig 6a-f and Figure 10a-m. When a template was created by the anonymous person, users were encouraged to freely use their imagination and create personalised visual messages with humorous and sarcastic subtexts. This made the creation of humour memes highly accessible to the ordinary man-in-the-street. Another technique adopted was the "image macro", which involves adding text onto an image to create a statement not intended by the original image. Examples of these include Fig $6 \mathrm{~g} \& 6 \mathrm{~h}$ and Figure 7a \& 7b. The ease with, which such graphics can be created, with websites like Image Shack (n.d.) quickmeme (n.d.) or Meme Generator (n.d.) means, once again, that anyone can create these pictures.

Additionally, it is of interest to note that the more popular SMRT memes fall under the textless category. This could mean that the pictures have the ability to transcend language barriers and were able to cross from the English-speakers to the Chinese heartlanders. It would be relevant to ask if the use of the Internet memes is breaking down the language divide in socio-political opinions in Singapore. Klotz (2004) had argued that one of the key weaknesses of advocacy through the Internet is the low accidental exposure to a campaign message as compared to television and radio. This argument would have been valid before the 
age of Facebook. Unlike pre-Facebook messages, which had to be consciously clicked on by the receipient to be accessed either in an email or a hyperlink leading to a static website, with Facebook links "shared" by friends are automatically posted in the Newsfeed page. The user therefore has a lot less discretion in selecting what he or she wishes to see and accidental exposure would be significantly higher. This can make a major difference in influencing fence-sitters who may now, due to the accidental exposure to an opposing or alternative viewpoint, be more open to consider its merit. The use of a meme, which succintly encapsulates a position without lengthy arguments makes it doubly powerful.

\subsection{The Internet eroding the grip of the authorities on the media}

Another question the SMRT affair raises is whether this is yet another sign of the shift of the role of opinion leader from traditional media producers to the media consumers themselves. According to Lim (2011), Singapore, at 67 per cent and up from 59 per cent (Wee 2009) in just two years, has the highest Internet penetration in Southeast Asia. In contrast, statistics show there is a downward trend for the circulation of English language newspapers, while Chinese newspapers are on a slight rise (Nielsen Media Index 2008, as cited by Tan 2008). In a survey by Singapore's Institute of Policy Studies 65.8 per cent of respondents aged 21-39 view the Internet as an important source of political news compared to 38.5 per cent for those between 40-59 and 27.3 per cent for those aged 60 and above (Tan et al 2011: 64). The SMRT episode, together with a number of other significant events that followed, like the General Election and Presidential Election in 2011, and a by-election in 2012, suggests that the government no longer have the control over public perception that it used to have because in both the General Election and the by-election, the government suffered significant losses (Adam \& Javier 2012). As for the Presidential Election, although the ruling party-backed candidate won, it was with a meagre 35.2 per cent of the popular vote and only a mere 0.34 per cent ahead of his nearest rival ("Presidential Elections" 2011).

\section{Conclusions}

The SMRT incident, albeit a minor event, stands out as significant in terms of impact. Ordinary citizens, normally frightened into compliance, submission and reticence, have long been denied a truly free public space to voice their feelings and thoughts. However, the Internet has provided a virtual public space, and through the convenient and creative use of technology, the people appear to be effecting change in the socio-political realm, hitherto the exclusive domain of politicians or activists. An unprecedented moral victory for the ordinary man in the street has been achieved; a minority of the citizenry has successfully influenced public opinion to force a government-linked public figure to accept responsibility for incompetence and negligence by stepping down. Although SMRT is not formally part of the government, Singaporeans nonetheless regard it as very much a part of the same exclusive club, because it is government-assisted and the board members are mostly connected to government departments, ministries or statutory boards in one way or another ("Board of Directors" 2012). It also appears that the public sphere is being gradually reclaimed by ordinary citizens via the Internet and Singaporeans are finding their voices after a long period of exclusion. It remains to be seen if this episode involving SMRT is a one-off situation where public outcry has shocked the people into a new culture of activism, or whether similar online protests and the use of such visual satire will increase in popularity in the future.

It should also be asked whether the effectiveness of this visual SMRT protest was particularly effective because of its novelty and, should it be used again, would the efficacy of 
the method be more or less impressive? While much scholarship has been devoted to the study of how the Internet is transforming the global political and economic landscape, including its effect of democratisation through the empowering of the disenfranchised (O’Neill 2010; Conroy, Feezell et al. 2012; Knudsen and Stage 2012; Saleh 2012; VesnicAlujevic 2012; Stephan 2013), the spaces of humour has been neglected, particularly in emerging democracies. This is unlike countries such as the United States of America where programmes like The Daily Show goes beyond "just for laughs" and actually provides a very influential voice in the public sphere through the use of satire. Pew Research Center's Project for Excellence in Journalism conducted a year-long content analysis of The Daily Show and was able to identify the very specific opinion leading roles it played. This resulted in Americans naming comedian Jon Stewart, host of The Daily Show, as the $4^{\text {th }}$ in a list of journalist they most admire-despite the fact that Stewart is not a journalist but a comedian ("Pew Research Center Publications" 2008). Warner (2007:19) describes Stewart's role as a political culture jammer similar to the jamming techniques employed by commercial competitors to call into question the branding techniques used by rivals to sell their products. Politicians similarly package and sell their political agenda using the same branding techniques, which are designed to "drown out dissident messages". Such use of humour can play a role "in opening up different ways of participating in public life without the demands for political capital or engaging in the scandal-based, aggressive and party-political debates that tend to be the main forms of political accountability" (Matheson 2012). These aspects of non-aggressive humour in the Singapore political landscape could possibly be more palatable to the criticism-shy PAP government and may contribute in a more positive national conversation that the government has promised.

\section{References}

Bawcutt, Priscilla, ed. (1998). The Poems of William Dunbar. 2 vols. Glasgow: Association for Scottish Literary Studies.

About DFS. (2012). Retrieved July 13, 2012, from DFS Galleria Singapore: http://www.dfsgalleria.com/en/singapore/about-dfs.

Adam, S.\& Javier, L.A. (2012, May 28). Singapore's PAP Fails to Regain Support in By-Election. Retrieved Jul 14, 2012, from Bloomberg: http://www.bloomberg.com/news/2012-0526/singapore-opposition-wins-by-election-to-retain-parliament-seat.html

Ang, P. (2007). Singapore Media. Retrieved June 9, 2012, from Journalism.sg: http://journalism.sg/wp-content/uploads/2007/09/ang-peng-hwa-2007-singapore-media.pdf

Anonymous X. (2011). Retrieved July 13, 2012, from Anonymous X: http://anonymousxwrites.blogspot.co.nz/2011_12_01_archive.html

AsiaOne (2011). Retrieved July 13, 2012, from AsiaOne: http://news.asiaone.com/A1MEDIA/news/12Dec11/images/20111218.165354_st_sawphaikhwa protest2.jpg).

Bland, B. (2009, Oct 5). Hossan Leong: Singapore's latter-day court jester. Retrieved June 16, 2012, from Asian Correspondent: http://asiancorrespondent.com/24617/hossan-leong-singaporeslatter-day-court-jester/

Board of Directors. (2012). Retrieved July 13, 2012, from SMRT: http://www.smrt.com.sg/AboutSMRT/Overview/BoardofDirectors.aspx

Cai, C. (2011, Dec 14). Radio DJ "in trouble" for reporting on Circle Line breakdown. Retrieved July 3, 2012, from Asia One: http://news.asiaone.com/News/Latest+News/Showbiz/Story/A1Story20111214-316234.html

Castells, M. (2008). The New Public Sphere: Global Civil Society, Communication Networks, and Global Governance. The ANNALS of the American Academy of Political and Social Science, 78-93. 
Chang, R. (2011, May 24). Singaporeans value growth over freedom of speech: Poll. Retrieved Jul 14, 2012, from The Straits Times: http://stqarender.asia1.com.sg/BreakingNews/Singapore/Story/STIStory 244718.html

Cheong, W.L. (2011). MRT overcrowding and CEO's "stupid remarks". Retrieved May 20, 2012, from: http://sg-quitters.blogspot.co.nz/2011/03/mrt-overcrowding-and-ceos-stupid.html

Cheong, W.L. (2011). MRT overcrowding and CEO's "stupid remarks".

Cheong, W.L. (2011, December 22). SMRT CEO Saw's personal transport in case of breakdowns! Retrieved from Sg-Quitter.blogspot: http://sg-quitters.blogspot.co.nz/2011_12_01_archive.html

Cheong, W.L. (2011, March 19). Cartoons. Retrieved Aug 1, 2012, from http://sgquitters.blogspot.sg/: $\quad$ http://sg-quitters.blogspot.sg/search/label/Cartoons?updated-max=201103-20T22:43:00-07:00\& max-results $=20 \&$ start $=40 \&$ by-date $=$ false

Chua, B. (1994, Dec 5). PM: no erosion of my authority allowed. The Straits Times (Singapore), p. Headline.

Conroy, M., J. T. Feezell, et al. (2012). Facebook and political engagement: A study of online political group membership and offline political engagement. Computers in Human Behavior. 28: 15351546.

Country Comparison. (2011, Jan 1). Retrieved June 12, 2012, from Index Mundi: http://www.indexmundi.com/g/r.aspx?v=67

De Clercq, G. (2006, Dec 20). Politics is no laughing matter in Singapore. Retrieved June 16, 2012, from Washington Post: http://www.washingtonpost.com/wpdyn/content/article/2006/12/20/AR2006122000094.html

Department of Statistics Singapore. (2012, June). Monthly Digest of Statistics Singapore. Retrieved June 12, 2012, from Department of Statistics Singapore: http://www.singstat.gov.sg/pubn/reference/mdsjun12.pdf

EDMW Times (2011). "Singapore's First Class Transport." 20 May 2012, from http://edmwtimes.blogspot.co.nz/2011/06/singapores-first-class-transport.html.

firephoenix1003. (2008, Apr 23). Mas Selamat -should DPM resign - 3 seconds and it is settled. Retrieved Jul 14, 2012, from You Tube video: http://www.youtube.com/watch?v=9R-Fwylg0tU

Fong, K. (2012, Jun 5). Facebook user apologises for calling MRT commuters "peasants". Retrieved July 13, 2012, from Singapore Yahoo News: http://sg.news.yahoo.com/facebook-userapologises-for-calling-mrt-commuters-\%E2\%80\%9Cpeasants\%E2\%80\%9D.html

Gimmler, A. (2001, Jul). Deliberative democracy, the public sphere and the Internet. Philosophy \& Social Criticism, 27(4), 21-39.

Habermas, J. (1991). The Structural Transformation of the Public Sphere: An Inquiry into a Category of Bourgeois Society. Cambridge, Massachusett: MIT Press.

Hammett, D. (2010). Political Cartoons, Post-Colonialism and Critical African Studies. Critical African Studies, 2(4), 1-26.

Heliker, J. (2011, Nov 3). Digital Media Consumption Increasing As Consumers Embrace Multiple Screens For News And Entertainment: Nielsen. Retrieved Jul 13, 2012, from Nielsen News: http://www.sg.nielsen.com/site/NewsReleaseNov062011.shtml

Human Development Index and its components. (n.d.). Retrieved June 11, 2012, from http://hdr.undp.org/en/media/HDR_2011_EN_Table1.pdf

Image Shack (n.d.). Retrieved 12 November, 2012, from http://img408.imageshack.us/img408/7296/template.gif.

Klotz, R. (2004). The politics of Internet communication. Maryland: Rowman \& Littlefield Publishing Group.

Lee, M. (2008, May 23). Singapore bans two porn websites in symbolic move. Retrieved June 9, 2012, from Reuters Life!: http://www.reuters.com/article/2008/05/23/us-singapore-Internet-oddidUSS2322899620080523

Lee, T. (2002, March). The politics of civil society in Singapore. Asian Studies Review, 23(1), 97 -

Lim, J. (2012, Aug 15). S'pore world's most affluent by GDP per capita. Retrieved Aug 17, 2012, from AsiaOne: business.asiaone.com/Business/News/Story/A1Story20120815-365526.html

Lim, M. (2011, July 11). Singaporeans Can't Get Enough of Digital Media: Nielsen. Retrieved July 13, 2012, from Nielsen: http://www.sg.nielsen.com/site/NewsReleaseJuly112011.shtml 
Loh, C. (2007, Nov 12). Singapore: Cracks in society are showing . Retrieved June 12, 2012, from Seniors World Chronicle: http://www.seniorsworldchronicle.com/2007/11/singapore-cracks-insociety-are-showing.html

Mahtani, S. (2012, March 1). Debate over blog limits intensifies in Singapore. Retrieved June 9, 2012, from Southeast Asia Realtime: http://blogs.wsj.com/searealtime/tag/lee-hsien-loong/

Matheson, D. (2012, September 12). Personal communication.

Memegenerator (n.d.). Retrieved 20 May, 2013, from http://memegenerator.net/create/instance.

Minister Yeo on OB markers and Internet. (1999, May 26). Retrieved June 16, 2012, from Singapore Window: http://www.singapore-window.org/sw99/90526st.htm

Mokhtar, F. (2011, Aug 5). 1 percent transport fare hike sparks debate online. Retrieved July 3, 2012, from Yahoo News Singapore: http://sg.news.yahoo.com/blogs/singaporescene/public-transportcouncil-approves-1-per-cent-fare-024419341.html

MRT breakdown: Don't break the windows, says SMRT. (2011, Dec 17). Retrieved Jul 3, 2012, from The Straits Times Online: http://www.straitstimes.com/The-Big-Story/The-Big-Story3/Story/STIStory_745972.html

MRT breakdown: Emergency power should have kicked in. (2011, Dec 17). Retrieved July 3, 2012, from The Straits Times: www.straitstimes.com/The-Big-Story/The-Big-Story3/Story/STIStory $745976 . h t m l$

No laughing matter. (2001, May 24). Retrieved June 16, 2012, from Economist: http://www.economist.com/node/634418

O'Neill, B. (2010). The media's role in shaping Canadian civic and political engagement. Policy and Society. 29: 37-51.

Papacharissi, Z. (2002). The virtual sphere: The Internet as a public sphere. New Media \& Society, 927.

Parliamentary General Election. (2011). Retrieved June 12, 2012, from Singapore Elections: http://www.singapore-elections.com/parl-2011-ge/

Pew Research Center Publications. (2008, May 8). Retrieved Sept 14, 2012, from The Daily Show: Journalism, Satire or Just Laughs?: http://pewresearch.org/pubs/829/the-daily-show-journalismsatire-or-just-laughs

Population in Brief 2011. (2011, September). Retrieved Sept 13, 2012, from Department of Statistics in Singapore: http://www.singstat.gov.sg/stats/themes/people/popinbrief2011.pdf

Presidential Elections. (2011, Aug 1). Retrieved Jul 14, 2012, from Elections Department Singapore: http://www.eld.gov.sg/gazette_presidential.html

Press Freedom Index. (2011). Retrieved June 9, 2012, from Reporters Without Borders: http://en.rsf.org/press-freedom-index-2011-2012,1043.html

quickmeme: make (n.d.). Retrieved 20May, 2013, from (http://www.quickmeme.com/make/)

Ramesh, S. \& Soh, A. (2011, December 17). MRT breaks down again. Retrieved July 3, 2012, from Channel News Asia: http://www.channelnewsasia.com/stories/singaporelocalnews/view/1171888/1/.html

Rodan, G. (n.d.). The Internet and Political Control in Singapore. Retrieved June 09, 2012, from United Nations Public Administration Network: http://unpan1.un.org/intradoc/groups/public/documents/apcity/unpan002726.pdf

Saad, I. (2011, Dec 15). North-South MRT Line breakdown hits thousands. Retrieved July 3, 2012, from Channel News Asia: http://www.channelnewsasia.com/stories/singaporelocalnews/view/1171573/1/.html

Saleh, N. (2012). "Egypt's digital activism and the Dictator'sDilemma: An evaluation." Telecommunications Policy 36: 476-483.

Seah, C. (2011, Oct 31). Winning Chinese-speaking heartland key for WP. Retrieved Jul 13, 2012, from Yahoo! News, Singapore Scene: http://sg.news.yahoo.com/blogs/singaporescene/winningchinese-speaking-heartland-imperative-wp-092338813.html

Singapore backlash against political pay rates despite cut. (2012, Jan 4). Retrieved Jul 15, 2012, from The

http://www.telegraph.co.uk/news/worldnews/asia/singapore/8991540/Singapore-backlashagainst-political-pay-rates-despite-cut.html 
Singapore Seen (2010). "Graffiti on train: 'Cane the foreign vandal and act against MRT staff for security lapse'" Retrieved July 13, 2012, from The Straits Times Stomp: http://singaporeseen.stomp.com.sg/stomp/3552/4132/386278

Singapore: 'Textbook Example' of Repressive State. (2010, Jan 20). Retrieved June 9, 2012, from Human Rights Watch: http://www.hrw.org/news/2010/01/20/singapore-textbook-examplerepressive-state

SMRT CEO dressed up as 'queen' (2011, December 20). Retrieved July 13, 2012, from http://www.asiaone.com/Multimedia/Photo\%2BGallery/Story/A1Gallery20111220-2929.html

SMRT CEO gets her own Failure Demotivational Poster (2011, Dec 16). Retrieved July 11, 2012, from I.Z. Reloaded: daily online refreshments http://izreloaded.blogspot.co.nz/2011_12_01_archive.html

SMRT CEO not stepping down. (2011, Dec 18). Retrieved July 11, 2012, from Channel News Asia: http://www.channelnewsasia.com/stories/singaporelocalnews/view/1172082/1/.html

SMRT CEO Saw Phaik Hwa resigns. (2012, January 6). Retrieved July 13, 2012, from Channel News Asia: http://www.channelnewsasia.com/stories/singaporelocalnews/view/1175196/1/.html

SMRT Home. (2008-2012). Retrieved Jun 23, 2012, from SMRT: http://www.smrt.com.sg/

SMRT president in the hot seat. (2011, Dec 12). Retrieved July 13, 2012, from Asia One News: http://news.asiaone.com/News/AsiaOne+News/Singapore/Story/A1Story20111218316922.html

Spore Says Political Cartoon. (2012). Retrieved Jul 14, 2012, from Sporesays.blogspot: http://sporesays.blogspot.sg/

Stephan (2013). "Creating Solidarity in Cyberspace." Journal of Middle East Women's Studies 9(1): 81-109.

Suparto, I. (2010, Jun 21). Swiss man in MRT graffiti case set to enter plea . Retrieved Jun 23, 2012, from

AsiaOne:

http://www.asiaone.com/News/AsiaOne+News/Singapore/Story/A1Story20100621223197.html

Tan, L. (2008, Oct 30). The slow decline of newspapers and television. Retrieved Jul 13, 2012, from Red Sports: http://redsports.sg/2008/10/30/singapore-sports-story-online/

Tan, T.H. et al. (2011, May). Survey on Political Traits and Media Use. Retrieved Jul 14, 2012, from National University of Singapore Institute of Policy Studies: http://www.spp.nus.edu.sg/ips/docs/pub/survey reports/Media\%20Survey\%20Report 230511.p df

Teoh, $\bar{H}$. (2011, Aug 17). MRT train vandalised at Bishan depot. Retrieved Jun 23, 2012, from AsiaOne: http://www.asiaone.com/News/AsiaOne+News/Singapore/Story/A1Story20110817294968.html

the mrbrown show (video): TalkingCock in Parliament, Hossan Leong. (2006, August 24). Retrieved June 169, 2012, from The mbrownshow: http://www.mrbrownshow.com/?p=235

Vesnic-Alujevic, L. (2012). "Political participation and web 2.0 in Europe: A case study of Facebook." Public Relations Review 38 466- 470.

Warner, J. (2007). Political Culture Jamming: The Dissident Humor of The Daily Show With Jon Stewart. Popular Communication, 17-36.

Wee, S. (2009, Oct 22). Mass Media Continues to Perform in Times of Downturn: Nielsen. Retrieved Jul 13, 2012, from Nielson: http://sg.nielsen.com/site/20091022.htm

Williams, L. (2011, Dec 19). North Korean leader Kim Jong-il dies 'of heart attack'. Retrieved July 13, 2012, from BBC News Asia: http://www.bbc.co.uk/news/world-asia-16239693 